\title{
Panduan untuk Menerapkan Analisis Multikriteria dalam Menilai Kriteria dan Indikator
}

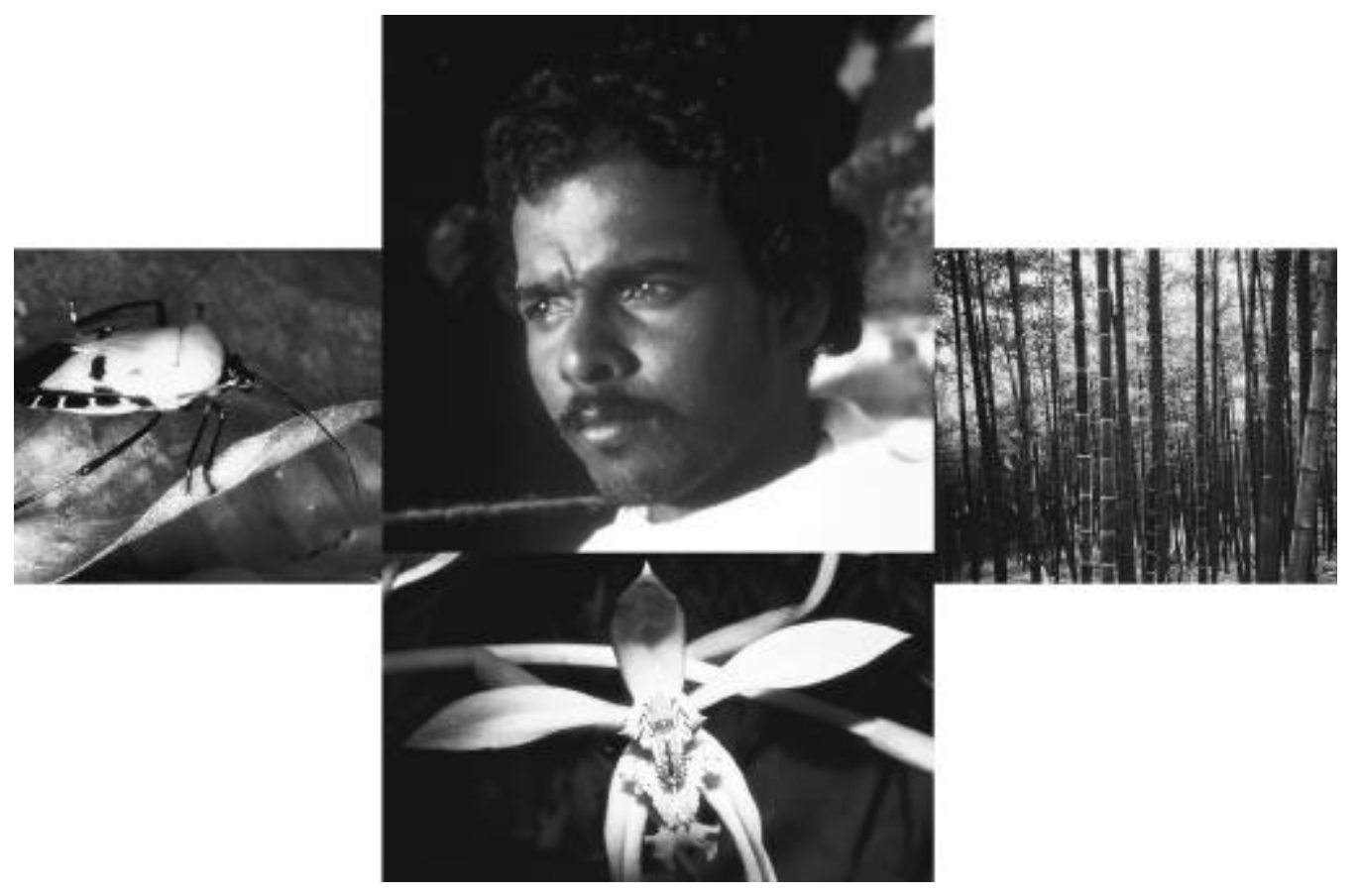


(C) 1999 oleh Center for International Forestry Research

Dicetak oleh SMKGrafikaMardiYuana, Bogor

Fotografi

Kumbang Pentatomidae oleh Paul Zborowski

Perkebunan bambu Phyllostachys pubescense oleh Christian Cossalter

Seorang biarawan di suatu hutan keramat, India oleh Paul S. Sochaczewski

Anggrek hitam Coelogyne pendurata oleh Plinio Sist

Para penulis ingin menyatakan penghargaan kepada Herlina Hartanto, Herry Purnomo, Daju Pradnja Resosudarmo, Rahayu Koesnadi, Agus Salim, Abdurrahman Syebubakar, Meilinda Wan dan Yurdi Yasmi yang melakukan pengecekan kualitas terjemahan seri perangkat ini, dan juga kepada Meiske D. Tapilatu dan Dwiati Novita Rini yang melakukan pengecekan selama proses persiapan pencetakan.

ISBN: 979-8764-41-2

Diterbitkan oleh

Center for International Forestry Research (CIFOR)

Alamat: PO Box 6596 JKPWB, Jakarta 10065, Indonesia

Telepon:+62-251-622 622 Fax: +62-251-622100

E-mail:cifor@cgiar.org

WWW: http://www.cgiar.org/cifor

Dengan dukungan dana dari

The European Commission

Anggaran B7-6021 yang berkaitan dengan 'Hutan Tropis'

Brusel, Belgia

Deutsche Gesellschaft für Technische Zusammenarbeit (GTZ) GmbH

Eschborn, Jerman

United StatesAgency for International Development (USAID)

Washington D.C.,Amerika Serikat

Pencetakan edisi bahasa Indonesia ini sebagian besar didanai oleh kantor Ford Foundation di Indonesia. 


\title{
PANDUAN UNTUK MENERAPKAN ANALISIS MULTIKRITERIA DALAM MENILAI KRITERIA DAN INDIKATOR
}

Guillermo A. Mendoza dan Phil Macoun

\author{
Bersama \\ Ravi Prabhu, Doddy Sukadri \\ Herry Purnomo, Herlina Hartanto
}

Alih bahasa

Ani Kartikasari dan Rita Maharani 


\section{Seri Perangkat K\&I}

\begin{tabular}{|c|c|}
\hline Perangkat K\&I No. 1 & $\begin{array}{l}\text { Panduan untuk Pengembangan, Pengujian dan Pemilihan } \\
\text { Kriteria dan Indikator untuk Pengelolaan Hutan Lestari } \\
\text { Prabhu, R., Colfer, C.J.P. dan Dudley, R.G. }\end{array}$ \\
\hline Perangkat K\&I No. 2 & $\begin{array}{l}\text { Acuan Generik Kriteria dan Indikator CIFOR } \\
\text { Tim KEI CIFOR }\end{array}$ \\
\hline Perangkat K\&I No. 3 & $\begin{array}{l}\text { Perangkat Modifikasi dan Adaptasi Kriteria dan Indikator } \\
\text { (CD-ROM) } \\
\text { Prabhu, R., Haggith, M., Purnomo, H., Rizal, A., Sukadri, } \\
\text { D., Taylor, J. dan Yasmi, Y. }\end{array}$ \\
\hline Perangkat K\&I No. 4 & $\begin{array}{l}\text { Sistem Basis Data Kriteria dan Indikator CIFOR } \\
\text { McDougall, C., Isbadi, I.R., Santoso, L., Corless, M. dan } \\
\text { Purnomo, H. (ed.) }\end{array}$ \\
\hline Perangkat K\&I No. 5 & $\begin{array}{l}\text { Panduan Penilaian Dasar Kesejahteraan Manusia } \\
\text { Colfer, C.J.P., Brocklesby, M.A., Diaw, C., Etuge, P., Günter, } \\
\text { M., Harwell, E., McDougall, C., Porro, N.M., Porro, R., } \\
\text { Prabhu, R., Salim, A., Sardjono, M.A., Tchikangwa, B., Tiani, } \\
\text { A.M., Wadley, R.L., Woelfel, J. dan Wollenberg, E. }\end{array}$ \\
\hline Perangkat K\&I No. 6 & $\begin{array}{l}\text { Panduan Pendamping Penilaian Dasar Kesejahteraan } \\
\text { Manusia } \\
\text { Colfer, C.J.P., Brocklesby, M.A., Diaw, C., Etuge, P., Günter, } \\
\text { M., Harwell, E., McDougall, C., Porro, N.M., Porro, R., } \\
\text { Prabhu, R., Salim, A., Sardjono, M.A., Tchikangwa, B., Tiani, } \\
\text { A.M., Wadley, R.L., Woelfel, J. dan Wollenberg, E. }\end{array}$ \\
\hline Perangkat K\&I No. 7 & $\begin{array}{l}\text { Panduan Cara Pemberian Skor dan Analisis untuk Menilai } \\
\text { Kesejahteraan Manusia } \\
\text { Salim, A. dan Colfer, C.J.P., dengan McDougall, C. }\end{array}$ \\
\hline Perangkat K\&I No. 8 & $\begin{array}{l}\text { Siapa yang Perlu Diperhitungkan? Menilai Kesejahteraan } \\
\text { Manusia dalam Pengelolaan Hutan Lestari } \\
\text { Colfer, C.J.P., Prabhu, R., Günter, M., McDougall, C., Porro, } \\
\text { N.M. dan Porro, R. }\end{array}$ \\
\hline Perangkat K\&I No. 9 & $\begin{array}{l}\text { Panduan untuk Menerapkan Analisis Multikriteria dalam } \\
\text { Menilai Kriteria dan Indikator } \\
\text { Mendoza, G.A., dan Macoun, P. dengan Prabhu, R., Sukadri, } \\
\text { D., Purnomo, dan Hartanto, H. }\end{array}$ \\
\hline
\end{tabular}

Perangkat K\&I No. 10 Metodologi untuk Menilai Indikator Ekologis dalam Pengelolaan Hutan Lestari (Dalam Persiapan) 


\section{DAFTAR ISI}

1. Latar Belakang .................................................................................. 1

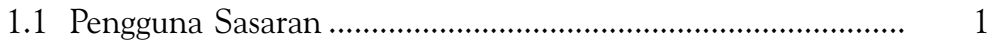

1.2 Struktur Panduan ................................................................. 2

1.3 Kegunaan Panduan.................................................................. 4

2. Konsep-konsep yang Diterapkan: K\&I dan AMK ……................... 7

2.1 Tinjauan Kerangka Konsep untuk Kriteria dan Indikator

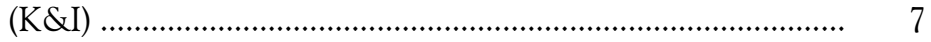

2.1.1 Memahami Prinsip, Kriteria dan Indikator .................. 7

2.1.2 Hierarki K\&I ............................................................. 9

2.2 Pengantar untuk Analisis Multikriteria ................................... 10

2.2.1 Penetapan Peringkat dan Penetapan Nilai ................... 12

2.2.2 Proses Hierarki Analitik (PHA) dan Perbandingan Berpasangan ................................................................... 13

2.3 Mengapa menggunakan AMK dalam Penilaian K\&I ............ 14

3. Menerapkan AMK dalam Penilaian K\&I ...................................... 19

3.1 Pengantar untuk Pendekatan Top-down dan Bottom-up ......... 19

3.2 Hal-hal yang Berkaitan dengan Pengorganisasian ................. 22

3.2.1 Tim Pakar ................................................................. 22

3.2.2 Panduan untuk Mengumpulkan Data .......................... 24

3.2.2.1 Pemungutan Suara .......................................... 24

3.2.2.2 Pengumpulan Data dan Analisis ................... 25

3.2.3 Memilih Metode Analisis yang Sesuai ........................ 26

3.3 Perincian Prosedur ............................................................... 29

3.3.1 Penyeleksian Set K\&I: Langkah Pertama ..................... 29

3.3.1.1 Penetapan Peringkat ........................................ 29

3.3.1.2 Penetapan Nilai ............................................... 33

3.3.1.3 Penghitungan Bobot Relatif ........................... 35 
3.3.2 Pemberian Skor: Langkah Kedua ................................ 38

3.3.3 Penilaian Unit Pengelolaan Hutan: Langkah Ketiga ... 39

4. Penerapan PHA yang Lebih Spesifik: Perbandingan Berpasangan ... 41

4.1 Perbandingan Berpasangan ......................................................... 41

4.1.1 Mengumpulkan Data ................................................ 42

4.1.2 Menghitung Bobot Relatif ........................................... 44

4.2 Menghitung Indeks Ketidak-konsistenan (I.K.) ..................... 48

4.3 Meningkatkan Konsistensi Penilaian (bagi tiap pakar) .......... 50

5. Pendekatan Bottom-Up dan Pengelolaan Hutan ............................. 55

5.1 Studi Kasus: Kalimantan Tengah ............................................ 56

6. Daftar Pustaka dan Bacaan Lebih Lanjut ....................................... 61

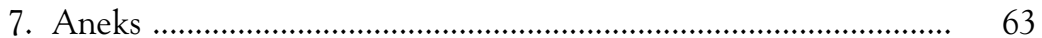

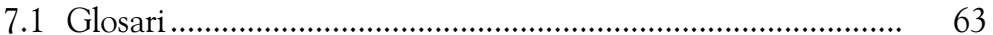

7.2 Lembar Pengumpulan Sampel Data ........................................ 65

7.3 Pola Generik Kriteria dan Indikator CIFOR ......................... 68

Daftar Gambar

Gambar 1: Hierarki Struktur K\&I ......................................................... 9

Gambar 2: Contoh Hubungan Informasi dalam Hierarki K\&I ......... 10

Gambar 3: Aplikasi Teknik AMK dalam Seleksi dan Pemberian Skor K\&I ........................................................................... 28

Daftar Tabel

Tabel 1: Penetapan Peringkat dan Penetapan Nilai Kriteria yang Relevan dengan Prinsip 2 .................................................... 35

Tabel 2: Jumlah Nilai untuk Tiap Kriteria ........................................ 36 
Tabel 3: Hasil Penghitungan Bobot Relatif untuk Teknik Penetapan Peringkat dan Penetapan Nilai .......................................... 36

Tabel 4: Penghitungan Bobot Gabungan untuk Tiap Kriteria .......... 37

Tabel 5: Penghitungan Skor Akhir untuk Kriteria K. 2.1 ................. 40

Tabel 6: Bobot Relatif Dihitung Menggunakan Perbandingan

Berpasangan untuk Empat Pakar ....................................... 46 


\section{Latar Belakang}

\subsection{PENGGUNA SASARAN}

Panduan ini ditulis untuk pengguna yang memerlukan panduan yang jelas dan mudah diikuti untuk menerapkan Analisis Multikriteria (AMK) di lapangan. Latar belakang matematika memang diperlukan, tapi bukan merupakan syarat yang mutlak untuk dapat menerapkan teknik-teknik yang akan dijelaskan dalam panduan ini.

Kami mengharapkan panduan ini akan berguna untuk mereka yang akan menggunakan AMK sebagai perangkat pengambilan keputusan untuk penilaian, evaluasi dan seleksi Kriteria dan Indikator (K\&I). Para pengguna dapat meliputi:

- Lembaga sertifikasi yang menilai pengelolaan HPH untuk kepentingan sertifikasi;

- Pejabat pemerintah yang merancang kebijakan-kebijakan kehutanan dan sektor lain yang terkait untuk pengelolaan yang lebih lestari;

- Lembaga donor yang mengevaluasi kelestarian berbagai kegiatan yang dilakukan oleh berbagai proyek pengelolaan sumber daya alam;

- Pengelola hutan yang ingin meningkatkan kelestarian pengelolaannya pada tingkat pengelolaan hutan;

- Pengelola proyek yang merencanakan, melaksanakan dan mengevaluasi proyek-proyek konservasi. 


\subsection{STRUKTUR PANDUAN}

Panduan ini dapat dibaca secara berurutan atau tidak berurutan. Informasi di dalamnya disusun agar dari bagian pertama pembaca diperkenalkan pada konsep-konsep umum yang terkait sebelum mempelajari penerapan AMK secara spesifik. Kami berharap penggunaan panduan ini dapat disesuaikan dengan pengetahuan dan latar belakang informasi yang dimiliki oleh pembaca. Untuk membantu pembaca dalam menemukan informasi yang berhubungan, sinopsis singkat untuk tiap bagian disajikan di bawah ini.

Bab 2 meninjau kerangka konsep K\&I dan memperkenalkan latar belakang teori AMK, terutama Proses Hierarki Analitik (PHA). Metode-metode spesifik AMK dan landasan bagi penggunaan AMK bersama K\&I juga dicantumkan.

Bab 3 merinci bagaimana AMK dapat diterapkan pada K\&I dalam konteks Sertifikasi Hutan. Termasuk di dalamnya subbagian berikut:

Bab 3.1 menjelaskan mengenai perbedaan antara pendekatan Top-down dan Bottom-up untuk menyeleksi dan mengevaluasi K\&I dengan AMK. Untuk kepentingan panduan ini Sertifikasi Hutan dianggap sebagai pendekatan top-down.

Bab 3.2 menjelaskan bahwa karena AMK merupakan suatu alat pengambilan keputusan, maka harus melibatkan partisipasi aktif para pengambil keputusan. Agar dapat menjadi suatu alat yang berguna, AMK perlu dipaparkan dengan jelas kepada para pembuat keputusan, dan diadaptasikan agar sesuai dengan kebutuhan khususnya. Bagian ini juga menjelaskan beberapa masalah yang harus dipertimbangkan pada saat bekerja dengan kelompok yang berbeda, dan memberikan beberapa saran umum untuk 
menyusun proses berdasarkan pengalaman yang diperoleh dengan menguji metode ini di lapangan.

Bab 3.3 menjelaskan keseluruhan proses untuk memasukkan AMK ke dalam analisis K\&I (sebagai suatu alat pengambilan keputusan) dengan menggunakan perangkat sederhana yaitu Penetapan peringkat dan Penetapan nilai. Analisis untuk Penetapan peringkat dan Penetapan nilai diperkenalkan langkah demi langkah, menurut cara 'buku resep'. Fokus penggunaan teknikteknik ini adalah untuk meringkas set K\&I yang umum, sehingga teknikteknik ini mencerminkan kondisi-kondisi dalam suatu contoh Unit Pengelolaan Hutan (UPH) ${ }^{1}$.

Bab 4 menjelaskan cara menggunakan teknik Perbandingan Berpasangan dan Indeks Ketidak-konsistenan (I.K.) untuk meningkatkan kepekaan analisis dan membantu memudahkan proses pengambilan keputusan. Bagian ini akan menjelaskan langkah-langkahnya secara rinci, meliputi cara penerapan teknik-teknik analisis ini dalam beberapa contoh yang digunakan pada Bab 3.3.

Bab 5 membahas cara-cara menggunakan AMK dalam suatu situasi analisis bottom-up. Penelitian di lapangan untuk melihat keefektifan penggunaan khusus AMK ini masih terus berjalan, sehingga sulit memberikan 'rumus' yang efektif untuk melaksanakan bentuk analisis ini di lapangan. Walaupun demikian, teori yang mendukung pendekatan bottom-up mungkin berguna untuk situasi penelitian tertentu. Untuk alasan ini penjelasan mengenai pendekatan bottom-up dimasukkan ke dalam panduan ini.

1 Suatu UPH ditentukan sebagai suatu wilayah daratan yang sebagian besar mencakup hutan dengan batas yang jelas, dikelola untuk serangkaian tujuan yang jelas dan mengikuti suatu rencana pengelolaan jangka panjang (Prabhu dkk. 1996). 
Aneks. Aneks terdiri dari:

1. Glosari

2. Lembar Pengumpulan Sampel Data

3. Pola Generik Kriteria dan Indikator CIFOR untuk Pengelolaan Hutan Lestari

\section{Intisari}

Informasi yang berkaitan dengan struktur Panduan ini dapat ditemukan dalam Kotak Intisari pada bagian yang relevan.

\subsection{KEGUNAAN PANDUAN}

Hutan di seluruh dunia telah sangat banyak berkurang sehinggga mencapai tingkat yang mengkhawatirkan. Sebagai reaksi atas tekanan yang hebat terhadap sumber daya hutan, banyak sekali usaha dilakukan untuk mencari cara menentukan dan menilai kelestarian hutan yang dapat digunakan di seluruh dunia. Suatu konsep yang telah dikembangkan untuk memandu pengelola hutan yang masih tersisa adalah Pengelolaan Hutan Lestari (lihat kotak).

\section{Pengelolaan Hutan Lestari (PHL)}

Untuk keperluan panduan ini, kami menggunakan definisi yang diusulkan oleh Prabhu dkk. (1998):

'Satu rangkaian sasaran kegiatan dan hasilhasil yang konsisten dengan usaha mempertahankan atau meningkatkan integritas ekologi hutan dan memberikan sumbangan bagi kesejahteraan manusia, baik untuk sekarang maupun untuk masa depan'. 
Agar dapat melaksanakan Pengelolaan Hutan Lestari dengan sukses maka diperlukan pengembangan pengukur yang bersifat spesifik untuk lokasi tertentu dan dapat diuji di lapangan sehingga mencerminkan kondisi hutan. Sampai sekarang Center for International Forestry Research (CIFOR) telah berperan serta dalam suatu program kerjasama riset untuk mengembangkan dan menguji Kriteria dan Indikator (K\&I) lebih lanjut. K\&I adalah perangkat yang dapat digunakan untuk mengumpulkan dan mengkoordinir informasi sedemikian rupa sehingga berguna dalam membuat konsep, mengevaluasi, melaksanakan dan mengkomunikasikan Pengelolaan Hutan Lestari. Penelitian lain mengenai K\&I juga telah dilakukan oleh beberapa organisasi yang berbeda, misalnya: the Forest Stewardship Council (FSC, 1994), SGS Forestry (1994), Scientific Certification Systems (SCS, 1994), dan the Tropenbos Foundation (1997).

Salah satu tujuan proses ini adalah menghasilkan satu set Prinsip, Kriteria, Indikator dan Pengukur ${ }^{2}$ yang diakui secara internasional, yang setelah diadaptasikan dengan kondisi lokal diharapkan dapat digunakan oleh siapa saja yang juga ingin melakukan evaluasi kinerja dan/atau kelestarian berbagai operasi kehutanan.

Penetapan satu set K\&I untuk kondisi lokal merupakan sebuah proses yang kompleks. Oleh karena itu, proses pengambilan keputusan yang digunakan untuk memilih atau memodifikasi K\&I harus dapat mengatasi berbagai variabel, konsisten dan transparan. Proses pengambilan keputusan yang memenuhi berbagai persyaratan ini adalah Analisis Multikriteria (AMK).

\footnotetext{
${ }^{2}$ Definisi Prinsip, Kriteria, Indikator dan Pengukur dapat dilihat pada Bab 2.1.1.
} 


\section{Konsep-Konsep yang Diterapkan: K\&I dan AMK}

\subsection{TINJAUAN KERANGKA KONSEP UNTUK KRITERIA DAN INDIKATOR}

Panduan ini disiapkan bersamaan dengan Panduan untuk pengembangan, pengujian dan pemilihan Kriteria dan Indikator untuk Pengelolaan Hutan Lestari (Prabhu dkk., 1998). Untuk kepentingan para pengguna panduan ini, yang tidak terbiasa dengan Pedoman tersebut, maka suatu tinjauan singkat mengenai kerangka konsep K\&I diterangkan pada bagian selanjutnya. Tinjauan ini diringkas dari Prabhu dkk. (1998). Para pembaca disarankan merujuk pada dokumen asli untuk mendapatkan uraian lengkap mengenai kerangka tersebut.

\subsubsection{MEMAHAMI PRINSIP, KRITERIA, DAN INDIKATOR}

Dalam bagian ini, kami mendefinisikan tiga perangkat utama yang merupakan komponen-komponen penting dari kerangka K\&I, yaitu: Prinsip, Kriteria dan Indikator. Sebagai tambahan, kami juga menentukan definisi konsep Pengukur.

Beberapa definisi berikut digunakan untuk elemen tersebut di atas:

Prinsip: Suatu kebenaran atau hukum pokok sebagai dasar suatu pertimbangan atau tindakan. Prinsip-prinsip dalam konteks pengelolaan hutan lestari diperlakukan sebagai kerangka primer untuk mengelola hutan secara lestari. Prinsip-prinsip tersebut memberikan landasan pemikiran bagi Kriteria, Indikator dan Pengukur. Beberapa contoh dari Prinsip tersebut adalah: 
- Agar Pengelolaan Hutan Lestari dapat berlangsung, maka 'integritas ekosistem harus dipelihara atau ditingkatkan', atau

- Agar Pengelolaan Hutan Lestari dapat berlangsung, maka 'kesejahteraan manusia harus dapat dijamin'.

Kriteria: Suatu prinsip atau patokan untuk menilai suatu hal. Oleh karenanya suatu Kriteria dapat dilihat sebagai prinsip 'tingkat dua' yang menambah arti dan cara kerja dalam suatu prinsip tanpa membuatnya sebagai suatu pengukur kinerja secara langsung. Kriteria merupakan titik lanjutan di mana informasi yang diberikan oleh Indikator dapat digabungkan dan di mana suatu penilaian yang dapat dipahami menjadi lebih tajam. Prinsipprinsip membentuk titik akhir integrasi. Beberapa contoh dari Kriteria yang diterapkan dalam Prinsip pertama, yang diberikan di atas, adalah:

- Agar integritas ekosistem dipelihara atau ditingkatkan, 'beberapa fungsi utama dan proses-proses ekosistem hutan harus dipertahankan', atau

- Agar integritas ekosistem dipelihara atau ditingkatkan, 'beberapa proses yang melestarikan atau meningkatkan variasi genetis harus dipertahankan'.

Indikator: Suatu variabel atau komponen ekosistem atau sistem pengelolaan hutan apa saja yang digunakan untuk memperkirakan status Kriteria tertentu. Indikator membawa suatu 'pesan tunggal yang berarti'. 'Pesan tunggal' ini disebut informasi, yang mewakili suatu agregat dari satu atau lebih elemen data yang memiliki hubungan tertentu yang tetap. Contoh Indikator bila diterapkan pada Kriteria di atas adalah:

- Untuk memastikan bahwa berbagai proses yang melestarikan atau meningkatkan variasi genetis dipertahankan, kita dapat mempelajari 'perubahan yang terarah pada frekuensi allele atau genotipe'. 
Pengukur: Data atau informasi yang meningkatkan spesifitas atau kemudahan penilaian suatu Indikator. Pengukur memberikan perincian khusus yang menunjukkan atau mencerminkan suatu kondisi yang diinginkan dari suatu Indikator. Pada tahap keempat spesifisitas, Pengukur memberikan perincian spesifik yang akan menunjukkan atau mencerminkan kondisi yang diinginkan dari suatu Indikator. Pengukur memberi tambahan arti dan ketelitian pada suatu Indikator. Pengukur dapat juga dianggap sebagai subindikator. Contoh Pengukur bila diterapkan pada Indikator di atas:

- Perubahan yang terarah pada frekuensi allele atau frekuensi genotipe dapat ditentukan melalui pengukuran 'jumlah allele dalam populasi' secara berkala.

\subsubsection{HIERARKI K\&I}

Definisi dari tiga perangkat utama, termasuk Pengukur seperti yang digambarkan di atas memungkinkan untuk menyusun kerangka konsep K\&I. Prabhu dkk. (1998) menggambarkan Hierarki K\&I ini menurut cara berikut:

\section{Gambar 1. Hierarki Struktur K\&I}

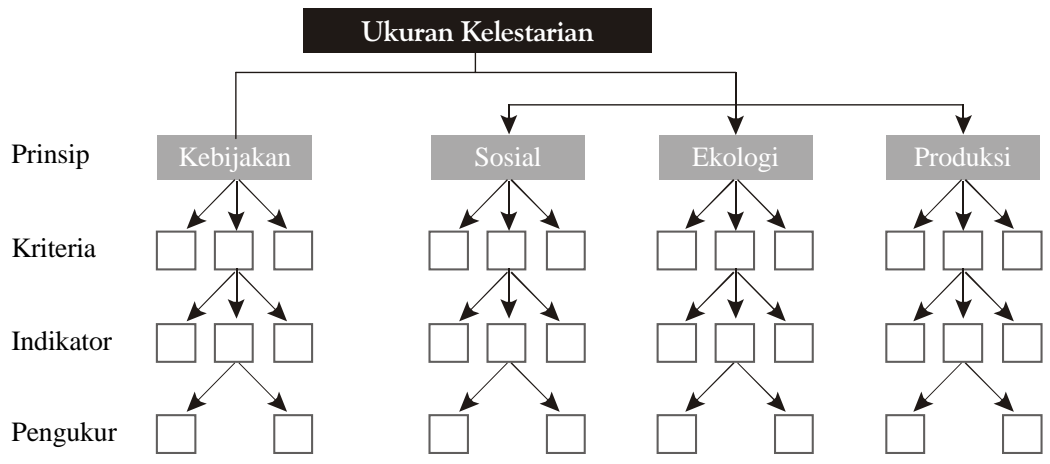




\section{Gambar 2. Contoh Hubungan Informasi dalam Hierarki K\&I}

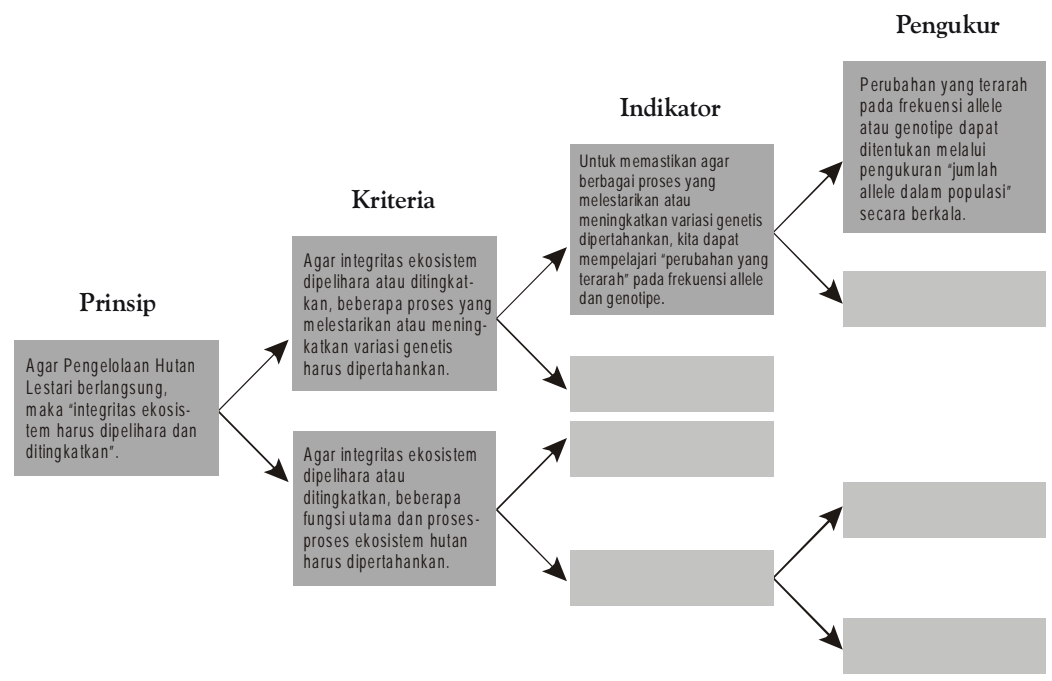

\subsection{PENGANTAR UNTUK ANALISIS MULTIKRITERIA}

\section{DEFINISI}

Analisis Multikriteria adalah perangkat pengambilan keputusan yang dikembangkan untuk masalah-masalah kompleks multikriteria yang mencakup aspek kualitatif dan atau kuantitatif dalam proses pengambilan keputusan. 


\section{MENGAPA ALAT UNTUK PENGAMBILAN KEPUTUSAN DIPER-}

\section{LUKAN?}

Dalam suatu situasi yang melibatkan berbagai kriteria, kerancuan mungkin akan terjadi jika suatu proses pengambilan keputusan yang logis dan terstruktur dengan baik tidak diikuti. Perhatikan contoh sederhana berikut ini:

Dua orang yang kehausan mencoba menentukan apakah akan membeli sekaleng 'Cola' atau sebotol Jus Jeruk

- Dua kriteria yang digunakan untuk mengambil keputusan ini adalah biaya dan manfaat bagi kesehatan dari masing-masing minuman.

- Orang pertama khawatir karena uang yang mereka miliki hanya sedikit dan ingin membeli Cola karena lebih murah.

- Orang kedua lebih memperhatikan hidup sehat dan umur panjang sehingga bersedia membayar Jus Jeruk yang lebih mahal tapi lebih menyehatkan.

Untuk mendapatkan suatu pilihan yang lebih disukai pada situasi ini, kepentingan relatif tiap kriteria (misalnya: biaya dan manfaat bagi kesehatan) terhadap keputusan yang telah dibuat harus dievaluasi dan dimasukkan ke dalam proses pengambilan keputusan. Jadi apabila biaya dianggap relatif lebih penting daripada manfaat bagi kesehatan, sekaleng Cola akan menjadi pilihan yang paling diinginkan. Tentunya kompleks dan sulit sekali untuk mencapai kesepakatan atas tingkat kepentingan relatif pada Kriteria yang berbeda. AMK adalah suatu perangkat yang dapat membantu mengevaluasi tingkat kepentingan relatif seluruh Kriteria yang terkait dan menggambarkan tingkat kepentingannya dalam proses pengambilan keputusan akhir. 
Kesulitan lain dalam pengambilan keputusan adalah untuk mencapai kesepakatan bersama dalam suatu tim yang terdiri dari berbagai disiplin ilmu. Dengan menggunakan AMK, para anggota tidak perlu sepakat mengenai tingkat kepentingan relatif dari Kriteria atau mengenai penetapan peringkat alternatifnya. Tiap anggota tim menyatakan pendapat pribadinya, dan memberi sumbangan masing-masing dalam rangka tercapainya kesimpulan yang disepakati bersama.

\section{Intisari}

- 2.2.1 dan 2.2.2 berisi tinjauan singkat mengenai teknik yang digunakan dalam AMK; Penetapan Peringkat; Penetapan Nilai; Perbandingan Berpasangan. Semua teknik ini dijelaskan secara terinci dalam bagian berikutnya.

- Dalam menetapkan teknik-teknik ini istilah yang digunakan adalah ‘elemen keputusan'. Istilah ini merupakan suatu acuan umum pada berbagai elemen yang berbeda dan perlu dianalisis untuk membuat keputusan yang kompleks. Dalam konteks analisis K\&I, elemenelemen ini dapat berupa beberapa Prinsip, Kriteria atau Indikator.

\subsubsection{PENETAPAN PERINGKAT DAN PENETAPAN NILAI}

Dua metodologi AMK yang paling sederhana dan dapat digunakan dalam suatu Penilaian K\&I adalah Penetapan Peringkat dan Penetapan Nilai.

Penetapan peringkat (Ranking) adalah pemberian suatu peringkat bagi tiap elemen keputusan yang menggambarkan derajat kepentingan relatif elemen tersebut terhadap keputusan yang dibuat. Elemen-elemen keputusan kemudian disusun berdasarkan peringkatnya (pertama, kedua, dst.). 
Penetapan nilai (Rating) mirip dengan penetapan peringkat, hanya elemenelemen keputusan diberi skor antara 0 dan 100. Seluruh skor elemen yang dibandingkan jumlahnya harus mencapai 100. Dengan demikian, apabila suatu elemen diberi skor tinggi, berarti elemen lainnya harus diberi skor lebih rendah.

\subsubsection{PROSES HIERARKI ANALITIK (PHA) DAN PERBANDINGAN BERPASANGAN}

Proses Hierarki Analitik (PHA) membantu pengambilan keputusan dengan menyusun komponen penting dari suatu masalah ke dalam suatu struktur hierarki yang menyerupai sebuah silsilah keluarga. Dalam konteks penilaian $\mathrm{K} \& \mathrm{I}$, metode PHA merupakan suatu perangkat pengambilan keputusan yang berguna karena sesuai dengan Hierarki Prinsip, Kriteria, Indikator dan Pengukur yang sudah ada (Bab 2.1.2).

Metode PHA memilah rangkaian keputusan yang kompleks menjadi satu seri perbandingan sederhana yang disebut Perbandingan Berpasangan, antara beberapa elemen Hierarki keputusan. Dengan membuat sintesis hasil perbandingan, PHA dapat membantu Anda untuk memperoleh keputusan terbaik dan memberikan alasan yang jelas untuk pilihan yang Anda buat.

Untuk informasi lebih lanjut tentang metode PHA, rujukan lain yang dapat dibaca adalah Mendoza (1997a, b), Saaty (1995), Golden dkk. (1989) dan Vargas dan Zahedi (1993).

Perbandingan Berpasangan secara singkat adalah cara menyaring K\&I yang kompleks untuk pemecahan masalah menjadi satu seri penilaian satu banding satu mengenai kepentingan relatif tiap Indikator terhadap Kriteria yang 
diuraikan. Kemudian tiap Indikator dalam suatu Kriteria dibandingkan dengan tiap Indikator lainnya dalam Kriteria itu untuk menilai tingkat kepentingan relatifnya.

\subsection{MENGAPA MENGGUNAKAN AMK DALAM PENILAIAN K\&I?}

Beberapa tantangan dalam penggunaan $\mathrm{K} \& \mathrm{I}$ untuk menilai kelestarian suatu kawasan hutan:

1. K\&I yang digunakan harus mencakup beragam barang dan jasa yang disediakan oleh hutan.

2. Informasi yang digunakan untuk menilai kelestarian sifatnya kualitatif dan kuantitatif.

3. Penilaian kelestarian harus melibatkan partisipasi berbagai kelompok pengguna hutan, stakeholder dan para pakar.

4. Pengambilan keputusan harus didasarkan atas kesepakatan bersama antara beberapa kelompok pengguna hutan yang mungkin sulit dicapai.

5. Analisis harus bersifat interaktif dan penilaian sebaiknya diberitahukan.

Catatan yang lebih terinci mengenai beberapa tantangan ini akan disajikan pada kotak berikut.

Mengingat kompleksnya proses penetapan keputusan, pengguna mungkin berpikir bahwa tantangan untuk mencapai suatu keputusan yang obyektif tidak dapat dicapai dengan menggunakan prosedur 'ad hoc'. Beberapa bahaya yang berhubungan dengan penggunaan prosedur ad hoc dalam tipe proses pengambilan keputusan ini adalah: 
- Makin tingginya risiko atau kemungkinan menghasilkan keputusan yang salah.

- Suatu prosedur ad hoc dapat memperburuk suatu keputusan yang salah karena tidak adanya 'track record' yang dapat membantu dalam memberi penjelasan mengenai alasan yang masuk akal dan logis di balik keputusan tersebut.

- Kurangnya transparansi pada proses pengambilan keputusan yang dapat menghalangi adopsi K\&I, atau lebih buruk lagi, hasil penilaian K\&I tidak diterima oleh masyarakat.

Analisis Multikriteria menyediakan alat yang sesuai untuk mengatasi beberapa tantangan yang dihadapi dalam penilaian K\&I; ciri-ciri spesifik AMK yang berguna diuraikan di bawah ini.

1. Kemampuan untuk menampung beragam kriteria dalam analisis.

2. AMK dapat menggunakan data campuran dan analisisnya tidak memerlukan banyak data. Metode ini memungkinkan penggabungan baik informasi kualitatif maupun kuantitatif.

3. AMK memungkinkan keterlibatan langsung berbagai pakar, kelompok pengelola hutan dan stakeholder.

4. Analisis bersifat transparan bagi para peserta.

5. AMK mencakup mekanisme umpan balik yang berkenaan dengan konsistensi dari penilaian yang dibuat.

Beberapa cara penerapan spesifik AMK dalam penilaian K\&I adalah:

- Sebagai satu cara untuk memudahkan pengambilan keputusan oleh tiap individu/peserta yang berkaitan dengan tingkat kepentingan tiap Kriteria/ Indikator. 
- Sebagai satu cara untuk menilai tingkat kepentingan relatif dari tiap kriteria/ indikator dalam upaya memilih satu set yang dianggap paling penting.

- Sebagai satu cara untuk mengumpulkan semua hasil evaluasi yang dibuat oleh para peserta, pakar untuk mencapai suatu konsensus atau evaluasi bersama untuk semua Kriteria/Indikator.

Akhirnya, dalam banyak situasi pengambilan keputusan, kemampuan untuk berkomunikasi dan menerangkan keputusan-keputusan dan bagaimana keputusan-keputusan tersebut dicapai, sama pentingnya dengan keputusankeputusan itu sendiri. Kemampuan AMK untuk memisahkan elemen keputusan dan menelaah kembali proses pengambilan keputusan, membuatnya ideal untuk menyampaikan dasar tiap keputusan. Suatu perangkat seperti ini diperlukan untuk mencapai keputusan bersama yang mudah disampaikan dan beralasan, berkenaan dengan penilaian $K \& I$. 


\section{Isu-isu dalam Penilaian K\&I}

1. K EI yang digunakan harus mencakup beragam barang dan jasa yang disediakan oleh hutan.

Hutan harus dikelola dengan cara yang dapat menampung dimensi-dimensi Sosial-Ekonomi, Biologi, Ekologi, Fisik dan Lingkungan dan setiap ekosistem. Pada hakikatnya ada kompleksitas di dalam sistem hutan sehingga tiap sistem pengukur harus dapat mengatasi kenyataan yang kompleks dan multidimensi ini.

2. Informasi yang digunakan untuk menilai kelestarian sifatnya kualitatif maupun kuantitatif.

Data kuantitatif adalah 'data keras' yang dapat dikumpulkan dan disintesis. Secara umum data keras sulit diperoleh dalam suatu situasi penilaian dan hanya dapat dimasukkan sebagai suatu variabel 'perwakilan' atau dalam beberapa cara kualitatif. Sebaliknya data kualitatif terutama untuk bagian yang bersifat konseptual. Contohnya faktor-faktor sosial dan lingkungan. Metode penilaian yang digunakan harus dapat menampung data kualitatif dan kuantitatif.

3. Penilaian kelestarian harus melibatkan partisipasi berbagai kelompok pengguna hutan, stakeholder dan para pakar.

Metode yang digunakan untuk menilai kelestarian sebaiknya sangat transparan bagi semua peserta dan stakeholder.

4. Pengambilan keputusan harus didasarkan atas kesepakatan bersama antara beberapa kelompok pengguna hutan yang mungkin sulit dicapai.

Sementara ada kesepakatan umum mengenai pentingnya mengukur kelestarian, tetapi hampir tidak ada kesepakatan dalam hal:

1) Bagaimana cara mengukur kelestarian.

2) Apa yang seharusnya tercakup dalam penilaian.

5. Analisis harus bersifat interaktif dan penilaian sebaiknya diberitahukan.

Analisis sebaiknya dapat mengubah informasi menjadi wawasan yang berguna bagi peserta untuk mencapai beberapa pilihan/evaluasi yang lebih mudah disampaikan. 


\section{$3 \begin{aligned} & \text { Menerapkan AMK } \\ & \text { Dalam Penilaian K\&I }\end{aligned}$}

\subsection{PENGANTAR UNTUK PENDEKATAN TOP-DOWN DAN BOTTOM-UP}

Ada dua pendekatan yang berbeda dalam penggunaan AMK yang tercakup dalam panduan ini, yaitu pendekatan top-down dan bottom-up. Tujuan proses top-down adalah untuk memastikan informasi konseptual yang benar dapat disimpan; tujuan proses bottom-up adalah untuk memastikan bahwa informasi, terutama yang berawal dari lapangan, tidak hilang (Prabhu dkk. 1996). Pilihan terhadap satu pendekatan dan tidak pada pendekatan lain, pada akhirnya akan bergantung pada sasaran penilaian dan beberapa kondisi lokasi yang dibicarakan.

\begin{tabular}{|l|}
\hline Intisari \\
\hline - Contoh-contoh yang digunakan dalam panduan ini menggambarkan perbedaan \\
metode AMK yang menggunakan pendekatan top-down yang diambil dari suatu \\
percobaan sertifikasi hutan di Kalimantan Tengah. \\
Model top-down memungkinkan dilakukannya pendekatan 'buku resep' seperti \\
dalam panduan ini. Menggunakan suatu tim pakar yang sudah terbiasa dengan \\
konsep dasar K\&I dan menggunakan Pola Generik sehingga pendekatan top- \\
down secara teoritis akan berhadapan dengan variabel yang lebih sedikit. Dengan \\
demikian model ini merupakan suatu model yang lebih baik bagi gaya penyajian \\
'buku resep'. \\
Informasi mengenai pendekatan bottom-up disaikan dalam Bab 5. Informasinya \\
disajikan sebagai panduan untuk melaksanakan pendekatan bottom-up atau \\
kombinasi kedua pendekatan, tetapi pembahasannya tidak menggunakan gaya \\
panduan 'buku resep'. Sebaliknya metode-metode, dan masalah-masalah yang \\
ditemukan selama uji lapangan oleh CIFOR dengan pendekatan 'quasi-bottom- \\
up' juga disajikan dalam panduan ini. \\
\hline
\end{tabular}


Walaupun Panduan ini mengulas kedua pendekatan ini secara terpisah, tidak berarti keduanya saling terpisah. Dalam banyak situasi, kombinasi kedua pendekatan ini akan menghasilkan kesimpulan-kesimpulan yang lebih baik. Pembahasan tentang pendekatan kombinasi ini terdapat dalam Bab 5.

\section{Pendekatan Top-down: Misalnya, Sertifikasi Hutan}

Pendekatan top-down paling sesuai digunakan dalam penilaian kinerja suatu Unit Pengelolaan Hutan; satu penerapan spesifiknya adalah Sertifikasi Hutan. Berikut ini adalah beberapa kekhususan suatu pendekatan penilaian top-down.

- Dalam pendekatan ini suatu set K\&I (Pola Generik CIFOR) yang dibuat sebelumnya digunakan sebagai perangkat awal dan sebagai dasar untuk menghasilkan perangkat akhir K\&I.

- Tim Penilai terdiri dari para profesional atau pakar yang mewakili berbagai disiplin ilmu yang ada dalam set K\&I.

- Fokus tim adalah:

1. mengadaptasi dan memodifikasi set awal K\&I pada situasi lokal, dan

2. memperkirakan tingkat kepentingan relatif tiap elemen dalam set $K \& I$ berkenaan dengan Kriteria yang dipilih. Beberapa Kriteria antara lain kemampuan untuk diaudit, kemampuan untuk diterapkan dan keefektifan biaya.

Secara umum pendekatan top down dapat digunakan baik sebelum maupun sesudah bekerja di lapangan. Pendekatan tersebut dapat digunakan sebelumnya untuk mempersingkat K\&I yang akan dievaluasi di lapangan, dan juga dapat digunakan sesudahnya sebagai cara untuk melakukan penilaian berdasarkan data yang dikumpulkan. Kotak teks pada halaman selanjutnya berisi sinopsis mengenai cara menggunakan pendekatan top- 
down dalam penilaian K\&I. Mungkin sangat berguna untuk mengacu kembali pada langkah-langkah ini sebagai suatu kerangka saat Anda bekerja dengan panduan ini.

\section{Pendekatan Bottom-up: Misalnya, Pengelolaan Hutan}

Pendekatan sengaja disusun dengan cara yang memungkinkan keterlibatan langsung dan partisipasi aktif berbagai stakeholder dalam Unit Pengelolaan Hutan. Dalam panduan ini kita melihat pendekatan bottom-up dari konteks Pengelolaan Hutan, berbeda dengan Sertifikasi Hutan.

\begin{tabular}{|c|c|}
\hline & $\begin{array}{l}\text { Skenario Pengelolaan Hutan } \\
\text { Pendekatan Top-down }\end{array}$ \\
\hline Langkah 1 & Tentukan suatu set awal K\&I (misalnya, Pola Ge \\
\hline Langkah 2 & $\begin{array}{l}\text { Tim Pakar mempelajari perangkat awal. Memodifikasi perangkat } \\
\text { tersebut bila diperlukan. }\end{array}$ \\
\hline Langkah 3 & $\begin{array}{l}\text { Tim memberikan penilaian individual bagi tiap Prinsip. Penilaian } \\
\text { individual dikumpulkan dengan menggunakan Formulir Respon 1A. }\end{array}$ \\
\hline Langkah 4 & $\begin{array}{l}\text { Tim memberikan penilaian individual bagi Kriteria pada tiap Prinsip. } \\
\text { Penilaian individual dikumpulkan dengan menggunakan Formulir } \\
\text { Respon 1B. }\end{array}$ \\
\hline Langkah 5 & $\begin{array}{l}\text { Berdasarkan hasil yang diperoleh dari langkah } 3 \text { dan } 4 \text {, buat prioritas } \\
\text { Prinsip dan Kriteria menurut Bobot Relatifnya. }\end{array}$ \\
\hline Langkah 6 & $\begin{array}{l}\text { Apabila memungkinkan, hilangkan Prinsip-prinsip dan Kriteria yang } \\
\text { bobotnya jauh lebih rendah daripada yang lainnya. }\end{array}$ \\
\hline Langkah 7 & $\begin{array}{l}\text { Dari Prinsip dan Kriteria lainnya yang dinilai penting, periksa Indikator } \\
\text { pada tiap Kriteria. Penilaian individual dikumpulkan dengan } \\
\text { menggunakan Formulir Respon } 2 \mathrm{~A} \text { dan } 2 \mathrm{~B} \text {. }\end{array}$ \\
\hline Langkah 8 & $\begin{array}{l}\text { Hitung Bobot Relatif tiap Indikator. Prioritaskan Indikator-indikator } \\
\text { menurut Bobot Relatifnya. Hilangkan Indikator-indikator yang } \\
\text { dianggap kurang penting. }\end{array}$ \\
\hline Langkah 9 & $\begin{array}{l}\text { Perlihatkan daftar terakhir kepada Tim. Jika Tim puas, Daftar Akhir } \\
\text { K\&I dalam ditetapkan. Jika Tim tidak puas, maka proses dapat } \\
\text { diulang dari Langkah kedua. }\end{array}$ \\
\hline
\end{tabular}


Pendekatan bottom-up tidak mudah dijelaskan dengan gaya ‘buku resep' seperti pendekatan top-down. Metode-metode penggunaan AMK dengan pendekatan ini juga belum sepenuhnya teruji di lapangan. Walaupun demikian, pendekatan bottom-up untuk pengambilan keputusan yang melibatkan para stakeholder lokal sangat penting dalam proses mana pun yang bertujuan mendapatkan suatu dampak yang lestari pada pengelolaan jangka panjang suatu UPH.

\subsection{HAL-HAL YANG BERKAITAN DENGAN PENGORGANISASIAN}

AMK sangat mengandalkan masukan dari para pakar dan stakeholder. Masukan-masukan ini dikumpulkan dan disintesis untuk memperoleh satu keputusan atau pilihan kolektif, berkaitan dengan seleksi satu set K\&I yang bobotnya telah dinilai. Beberapa pertanyaan yang relevan adalah:

- Tim yang bagaimana yang ingin Anda pilih?

- Bagaimana Anda akan menyusun proses pemungutan suara untuk memperoleh informasi yang relevan dari para pakar?

- Bagaimana Anda mengumpulkan dan menganalisis informasi yang Anda peroleh?

- Metodologi AMK yang bagaimana yang sesuai dengan sasaran analisis?

\subsubsection{TIM PAKAR}

Relevansi dan kekuatan AMK pada akhirnya bergantung pada pengetahuan dan pengalaman Tim Pakar yang terbentuk. Tim pakar perlu memahami hierarki K\&I, dan memiliki pengetahuan luas yang relevan dengan UPH yang bersangkutan. 
Pola Generik K\&I CIFOR terbagi dalam enam Prinsip umum yang berada di bawah empat kategori umum, yaitu: Sosial, Kebijakan, Integritas Ekologi dan Produksi (lihat Aneks 7.4 untuk informasi lebih lanjut). Kami menyarankan Tim Pakar paling sedikit terdiri dari enam pakar/anggota tim yang mewakili keahlian dalam tiap Prinsip. Keahlian ini dapat diperoleh melalui berbagai kombinasi pakar yang berbeda. Sebagai panduan, satu contoh Tim Pakar diberikan di bawah ini.

\section{Contoh suatu Tim Lokal}

Konteks: Sertifikasi Hutan pada sebuah HPH di Kalimantan Tengah

1. Ilmuwan Sosial yang mengkhususkan diri pada Kehutanan Sosial dan Pembangunan Masyarakat.

2. Ilmuwan Ekonomi Sumber Daya dengan keahlian ekonomi dan produksi hutan.

3. Ilmuwan Ekologis yang mengetahui benar masalah ekologi hutan Dipterocarpace di Kalimantan.

4. Ilmuwan Pengelolaan Hutan dengan pengetahuan kebijakan hutan dan sejarah pengelolaan hutan di Indonesia.

5. Ilmuwan Pengelolaan Hutan dengan keahlian di hutan-hutan Asia Tenggara.

6. Penilai Profesional dengan gelar pendidikan tinggi di bidang ilmu kehutanan, telah berpengalaman luas dalam sertifikasi.

Sebaiknya diusahakan untuk merekrut tenaga pakar terbaik yang ada, baik yang berlatar belakang ilmu yang terkait maupun dengan lokasi yang bersangkutan. Sedapat mungkin pastikan keragaman jender. Perspektif lain juga perlu disertakan dalam tim (misalnya para akademisi, konsultan, LSM, aparat pemerintah). Tim sebaiknya tidak terdiri dari sebuah kelompok 'orang dalam', yang terlalu akrab satu sama lain dan memiliki pandangan yang sangat seragam. Situasi ini akan mengurangi keragaman wawasan dan kualitas diskusinya. Gabungan pakar Nasional dan Internasional akan membantu memunculkan perspektif berbeda dalam proses yang berlangsung. 


\subsubsection{PANDUAN UNTUK MENGUMPULKAN DATA}

Agar dapat melaksanakan suatu analisis AMK dengan berhasil, struktur proses pemungutan suara yang digunakan oleh Tim Pakar, dan cara mengum-pulkan serta menganalisis data perlu dipertimbangkan dengan seksama.

\subsubsection{Pemungutan Suara}

Sebelum pemungutan suara dilakukan, perlu disediakan forum diskusi terbuka. Selama diskusi tersebut, para anggota tim sebaiknya menahan diri untuk bisa mengungkapkan dengan jelas bagaimana cara mereka dalam menetapkan skor, peringkat atau nilai untuk tiap elemen dalam hierarki K\&I. Cara ini akan membantu menjamin kebebasan penilaian tiap anggota dari pengaruh anggota tim lain yang lebih vokal.

Walaupun diskusi dilakukan secara terbuka, pemungutan suara sebaiknya dilakukan secara individual. Pemungutan suara dilakukan dengan mengisi Formulir Respon untuk tiap pendekatan AMK, tahap dan tingkat analisis, serta elemen keputusan dalam hierarki K\&I. Formulir contoh ada dalam Bab 3 dan Aneks 2.

Pada umumnya, paling baik bila kelompok berdiskusi dan melakukan pemungutan suara untuk satu Prinsip, Kriteria atau Indikator secara berurutan. Contohnya, apabila menghadapi Kriteria 1 untuk Prinsip 2 kelompok akan,

1. mendiskusikan tingkat kepentingannya secara bersama;

2. memungut suara secara individual dengan menggunakan Formulir Respon. 
Setelah pemungutan suara, diskusi dilanjutkan ke Kriteria 2 untuk Prinsip 2.

Komunikasi lintas disiplin yang efektif sangat diperlukan agar diskusi prapemungutan suara berhasil dengan baik. Empat sikap yang penting dalam meningkatkan komunikasi adalah:

- bersedia berkompromi secara wajar untuk memenuhi kepentingan para anggota tim lainnya;

- minat yang sungguh-sungguh dalam mempelajari bidang disiplin lainnya;

- rasa hormat yang tulus terhadap para anggota tim Anda dan penghargaan terhadap keahliannya; dan

- kesepakatan yang memadai di antara para anggota tim mengenai sasaran.

\subsubsection{Pengumpulan Data dan Analisis}

Beberapa contoh yang digunakan dalam Panduan ini menggunakan set data yang jumlahnya sedikit untuk kepentingan ilustratif. Dalam konteks suatu proses AMK yang sesungguhnya, set data yang digunakan akan lebih besar dan sulit dianalisis secara manual.

Kami menyarankan agar sebelum memulai analisis, siapkan Lembar Isian Excel yang berisi seluruh butir data yang ingin Anda kumpulkan. Contoh pada Bab 3.3 dapat dilihat untuk memberikan informasi mengenai judul dan label untuk tabel yang sesuai dengan analisis yang Anda pilih.

Sejumlah program komputer juga telah dikembangkan untuk membantu mengumpulkan dan menganalisis hasil-hasil AMK yang berbeda. Di bawah ini diberikan dua contoh, yaitu: 


\section{- CIMAT}

CIMAT adalah perangkat komputer CIFOR yang dikembangkan untuk memodifikasi dan mengadaptasi K\&I agar sesuai dengan situasi lokal. Pada saat ini CIMAT belum memiliki perangkat pendukung untuk pengambilan keputusan, tetapi menyediakan informasi mengenai AMK. Informasi lebih lanjut dapat dilihat pada Kotak Peralatan CIFOR.

- Aplikasi Perangkat Lunak Lainnya

Expert Choice Inc. telah mengembangkan perangkat lunak komputer sebagai pendukung pengambilan keputusan. Informasi lebih lanjut untuk produk-produk lainnya dapat ditemukan dalam Web site berikut: www.expertchoice.com

\subsubsection{MEMILIH METODE ANALISIS YANG SESUAI}

\section{Menetapkan Urutan Analisis}

Sebelum tim pakar memulai analisisnya, akan lebih bermanfaat bila memikirkan dahulu urutan analisis; dengan urutan seperti apa Prinsip, Kriteria dan Indikator akan diuji.

Dalam skenario Top-down seperti yang digunakan dalam pengujian untuk sertifikasi, Tim Pakar dapat memulai analisis pada tingkat Prinsip yang lebih konseptual, karena mereka memiliki pengetahuan mengenai hierarki K\&I. Namun demikian, tidak terlalu penting untuk memulai dari hierarki paling atas.

Pada beberapa situasi mungkin akan lebih berguna untuk memulai analisis pada tingkat Kriteria, atau bahkan Indikator. Tingkat yang lebih rendah ini 
tidak terlalu bersifat konseptual dan lebih didasarkan pada pengukuranpengukuran dan observasi-observasi yang konkrit. Dengan menganalisis Kriteria dan Indikator terlebih dahulu, Tim Pakar dapat membangun dasar pengetahuan yang akan membantu mereka untuk menganalisis tingkat Prinsip dengan lebih baik. Hal ini terutama berkaitan dengan situasi penilaian dengan pendekatan Bottom-up di mana tim pakar terdiri dari berbagai macam latar belakang pengalaman dan pendidikan (lihat Bab 5).

Urutan dalam menerapkan metodologi AMK yang berbeda juga perlu dipertimbangkan.

- Berdasarkan pengalaman uji lapangan, Penetapan peringkat dan Penetapan nilai paling baik digunakan sebagai perangkat penyaring awal karena cara ini dengan cepat mengeluarkan elemen-elemen $K \& I$ yang tidak cukup penting.

- Sebaliknya, Perbandingan berpasangan paling baik digunakan sebagai saringan halus yang dapat digunakan pada tahap lebih lanjut untuk menentukan elemen-elemen $K \& I$ mana yang paling tidak penting dan dapat direkomendasikan untuk dihapus. Cara ini juga dapat digunakan untuk menentukan bobot relatif suatu indikator dengan lebih akurat.

\section{Intisari}

Gambar 3 melukiskan beberapa cara metode Penetapan peringkat, Penetapan nilai dan Perbandingan berpasangan yang dapat disesuaikan dengan analisis K\&I. Akan sangat berguna untuk mengacu ulang bagan ini saat Anda mempelajari bagianbagian selanjutnya. 


\section{Gambar 3. Aplikasi Teknik AMK dalam Seleksi dan Pemberian Skor K\&I}

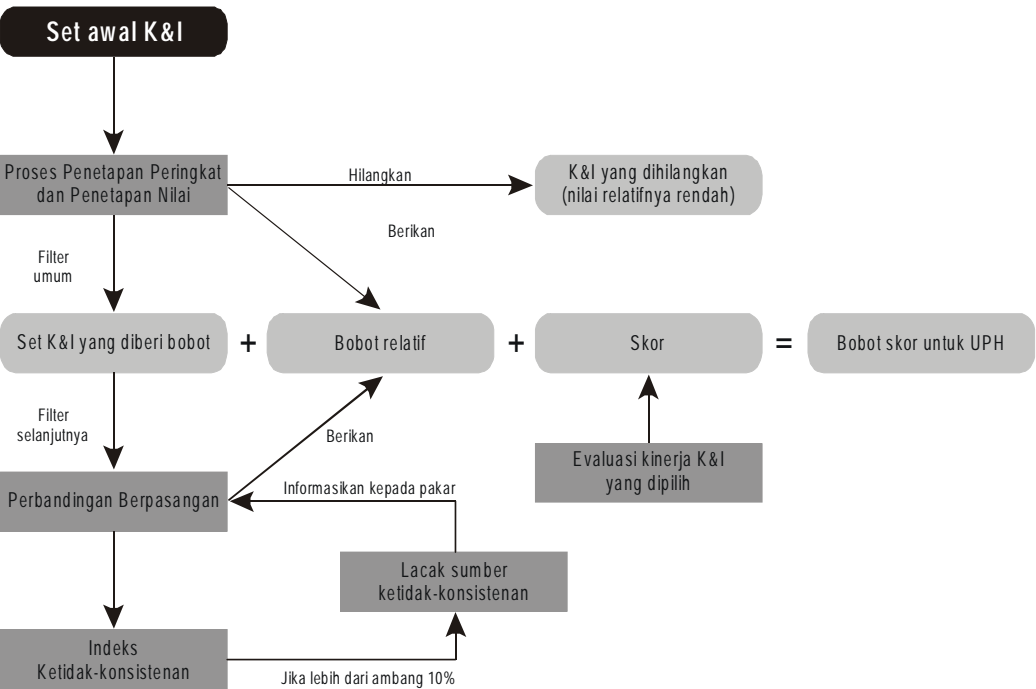

Keterangan: 


\subsection{PERINCIAN PROSEDUR}

Ada tiga langkah umum dalam penilaian K\&I. AMK dapat diterapkan secara spesifik sebagai suatu alat pengambilan keputusan dalam langkah 1 dan 3.

1) Identifikasi dan seleksi beberapa Kriteria dan Indikator.

2) Pemberian skor untuk beberapa Indikator berdasarkan set yang dipilih.

3) Penilaian UPH dalam hal ini seluruh penilaian kinerja pada semua tingkat hierarki K\&I.

Bagian ini menjelaskan tiga langkah tersebut menurut cara 'buku resep'.

\section{Intisari}

Pada beberapa contoh berikut ini beberapa singkatan akan digunakan untuk merujuk pada beberapa Kriteria dan Indikator. Misalnya,

- K. 2.1 = Kriteria (pada Prinsip 2). (Kriteria 1)

- I. 2.1.1 = Indikator (pada Prinsip 2). (Kriteria 1). (Indikator 1)

\subsubsection{PENYELEKSIAN SET K\&I: LANGKAH PERTAMA}

Dua teknik sederhana di mana AMK digunakan untuk mengidentifikasi dan menyeleksi K\&I yang relevan adalah Penetapan peringkat dan Penetapan nilai. Pada bagian ini akan dijelaskan definisi kedua teknik ini dan disediakan beberapa contoh mengenai cara penggunaannya.

\subsubsection{Penetapan Peringkat}

Terdapat dua cara yang berbeda untuk menetapkan peringkat bagi satu set elemen pengambilan keputusan, yaitu Peringkat Reguler dan Peringkat Ordinal. 


\begin{tabular}{|l|}
\hline Prinsip Kebijakan 1: \\
\hline $\begin{array}{l}\text { Kebijakan, perencanaan } \\
\text { dan kerangka kelemba- } \\
\text { gaan mendukung penge- } \\
\text { lolaaan hutan lestari. }\end{array}$ \\
\hline Kriteria: \\
\hline
\end{tabular}

K. 1.1 Dana untuk pengelolaan hutan selalu tersedia dan dalam jumlah yang memadai.

K. 1.2 Ada kebijakan ekonomi yang bersifat pence. gahan.

K. 1.3 Kebijakan nonkehutanan tidak mengganggu pengelolaan hutan.

K. 1.4 Ada daerah penyangga yang berfungsi dengan baik.

K. 1.5 Ada kerangka kerja legal yang melindungi akses terhadap hutan dan sumber daya hutan.

K. 1.6 Ada reinvestasi modal untuk berbagai pilihan kegiatan pemanfaatan hutan.

\section{Peringkat Reguler}

Definisi: Peringkat Reguler memberikan suatu 'peringkat' kepada tiap elemen yang relevan dalam proses pengambilan keputusan menurut tingkat kepentingannya. Peringkat ditetapkan menurut 9 titik skala berikut ini.

\begin{tabular}{|c|c|c|c|c|}
\hline 1 & 3 & 5 & 7 & 9 \\
\hline 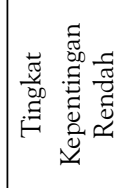 & 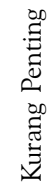 & 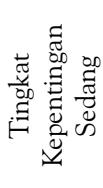 & 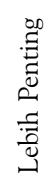 & 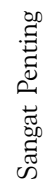 \\
\hline
\end{tabular}

Contoh: Pertimbangkan Prinsip Kebijakan, yang terdiri dari 6 Kriteria (K. 1.1 sampai K. 1.6). Tim Pakar diminta untuk menilai tingkat kepentingan relatif tiap Kriteria terhadap Prinsip Kebijakan pada khususnya, dan terhadap seluruh kelestarian hutan pada umumnya. Dalam penggunaan peringkat reguler seorang pakar mungkin bereaksi sebagai berikut: 


\begin{tabular}{|lcl|}
\hline Kriteria & Peringkat & Keterangan \\
\hline K. 1.1 & 6 & Tingkat Kepentingan Sedang \\
\hline K. 1.2 & 5 & Tingkat Kepentingan Sedang \\
\hline K. 1.3 & 5 & Tingkat Kepentingan Sedang \\
\hline K. 1.4 & 3 & Kurang Penting \\
\hline K. 1.5 & 4 & Tingkat Kepentingan Rendah sampai Sedang \\
\hline K. 1.6 & 2 & Tingkat Kepentingan Rendah sampai Sedang \\
\hline
\end{tabular}

\section{Peringkat Ordinal}

Definisi: Peringkat Ordinal adalah suatu teknik di mana tiap pakar diminta untuk menyusun daftar elemen keputusan menurut tingkat kepentingannya. Tidak seperti peringkat reguler di mana elemen keputusan yang berbeda dapat memperoleh peringkat yang sama, peringkat ordinal mengharuskan para pakar untuk menempatkan elemen-elemen dalam suatu hierarki tingkat kepentingan, tiap elemen dianggap relatif sangat atau kurang penting terhadap elemen-elemen lain yang terlibat.

Contoh: Dengan menggunakan Prinsip Kebijakan yang sama dengan yang telah diuraikan di atas, seorang pakar membuat urutan Kriteria sebagai berikut:

\begin{tabular}{|l|c|}
\hline Paling Penting & K. 1.1 \\
\hline & K. 1.2 \\
\hline & K. 1.3 \\
\hline & K. 1.5 \\
\hline & K. 1.4 \\
\hline Paling Tidak Penting & K. 1.6 \\
\hline
\end{tabular}

Perhatikan bahwa pada kasus ini pakar menentukan Kriteria 1.2 lebih penting daripada Kriteria 1.3. Dengan menggunakan metode Peringkat Reguler, kedua kriteria tersebut mendapatkan peringkat yang sama. 
Saat mempertimbangkan tipe Penetapan peringkat mana yang akan digunakan, penggunaan daftar kelebihan dan kelemahan berikut mungkin berguna:

\section{Peringkat Reguler:}

Kelebihan 1. Memungkinkan terjadinya 'seri'.

2. Pengambil keputusan dapat menetukan secara spesifik 'kualitas' tingkat kepentingan (nilai 1-9).

Kelemahan 1. Tidak cukup membedakan. Pengambil keputusan mungkin lebih memilih untuk memberikan penilaian yang sama.

\section{Peringkat Ordinal:}

Kelebihan 1. Sederhana, tidak ada keraguan dalam membuat 'urutan' tingkat kepentingan.

2. Membedakan 'derajat' kepentingan dengan jelas.

Kelemahan 1. Tidak ada 'seri'. Di dalam daftar tidak akan ditemukan dua elemen dengan tingkat kepentingan yang sama. Pengambil keputusan diharuskan untuk mengurutkan elemen-elemen keputusan saat mereka beranggapan kelompok elemen keputusan tersebut mempunyai 'derajat kepentingan yang hampir sama'.

2. Tidak ada 'kualitas' tingkat kepentingan (nilai1-9).

Peringkat Ordinal mungkin lebih sesuai untuk merampingkan satu set awal. Misalnya, apabila pengambil keputusan mencoba memilih 50 elemen dari satu set awal yang terdiri dari 200 elemen. 


\subsubsection{Penetapan Nilai}

\begin{tabular}{|lc|}
\hline Kriteria & Penetapan nilai \\
\hline K. 1.1 & 25 \\
\hline K. 1.2 & 20 \\
\hline K. 1.3 & 20 \\
\hline K. 1.4 & 12 \\
\hline K. 1.5 & 15 \\
\hline K. 1.6 & 8 \\
\hline Total & 100 \\
\hline
\end{tabular}

Definisi: Penetapan nilai merupakan suatu teknik di mana tiap pakar diminta untuk mem-berikan penetapan nilai bagi tiap elemen kepu-tusan, atau nilai persentase, antara 0 dan 100 . Jika dijumlahkan, nilai untuk semua elemen yang dibandingkan harus mencapai angka 100.

Contoh: Dengan menggunakan Prinsip Kebijakan yang sama dengan yang digunakan pada contoh di atas, seorang pakar mungkin akan memberikan penetapan nilai berikut ini pada Kriteria.

Kelebihan teknik Penetapan nilai adalah teknik ini menyediakan pengukuran tingkat kepentingan Ordinal dan Kardinal untuk tiap Indikator (lihat kotak). Sedangkan Penetapan peringkat hanya menyediakan pengukuran kepentingan Ordinal.

Agar dapat memberikan tingkat kepentingan Kardinal yang akurat untuk tiap indikator, Tim Pakar harus memiliki akses terhadap sejumlah besar informasi yang relevan. Hal ini tidak selalu tersedia selama suatu penilaian K\&I.

\section{Tingkat Kepentingan Ordinal:}

Merujuk pada urutan tingkat kepentingan dari elemen yang terlibat. Misalnya, mana yang pertama, kedua, dst.

\section{Tingkat Kepentingan Kardinal:}

Merujuk pada besarnya perbedaan kepentingan dua elemen. Misalnya, satu elemen mungkin tiga kali lebih penting daripada yang lainnya. 
Formulir Contoh untuk Pengumpulan Data Penetapan Peringkat dan Penetapan Nilai dari Tim Pakar

\section{Formulir Respon 1B}

(Silakan merujuk pada Pola Generik CIFOR untuk Informasi Terinci Mengenai

Kriteria dan Indikator)

Deskripsi: Formulir Respon 1B dirancang untuk analisis Tingkat 2 pada Tahap 1. Tingkat 2 menjelaskan respon dari para responden mengenai pendapat mereka tentang tingkat kepentingan relatif tiap Kriteria terhadap Prinsip, pada khususnya, dan kelestarian hutan secara keseluruhan, pada umumnya.

Kegunaan Formulir: Formulir 1B berguna untuk memperkirakan tingkat kepentingan atau bobot tiap kriteria dari tiap Prinsip.

Pengkodean Kriteria: K.i.j; i adalah nomor indeks Prinsip; j adalah nomor indeks Kriteria.

\begin{tabular}{|c|c|c|c|c|c|c|}
\hline \multirow{3}{*}{\begin{tabular}{|l|} 
Prinsip 1 \\
Kriteria \\
\end{tabular}} & \multirow{3}{*}{ Peringkat } & \multirow{3}{*}{ Nilai } & \multirow{2}{*}{\multicolumn{3}{|c|}{$\begin{array}{l}\text { Bobot/Prioritas Relatif } \\
\text { (Diisi oleh Analis) }\end{array}$}} & \multirow{3}{*}{ Keterangan } \\
\hline & & & & & & \\
\hline & & & $\begin{array}{l}\text { Peringkat } \\
\text { (Prioritas) }\end{array}$ & $\begin{array}{c}\text { Nilai } \\
\text { (Prioritas) }\end{array}$ & $\begin{array}{c}\begin{array}{c}\text { Keseluruhan } \\
\text { (Prioritas) }\end{array} \\
\end{array}$ & \\
\hline \multicolumn{7}{|l|}{ K. 1.1} \\
\hline \multicolumn{7}{|l|}{ K. 1.2} \\
\hline \multicolumn{7}{|l|}{ K. 1.3} \\
\hline \multicolumn{7}{|l|}{ K. 1.4} \\
\hline \multicolumn{7}{|l|}{ K. 1.5} \\
\hline K. 1.6 & & & & & & \\
\hline & & Total $=100$ & & & & \\
\hline
\end{tabular}

\begin{tabular}{|l|l|l|l|l|l|l|}
\hline Prinsip 2 & \multirow{2}{*}{ Peringkat } & Nilai & \multicolumn{3}{|c|}{$\begin{array}{c}\text { Bobot/Prioritas Relatif } \\
\text { (Diisi oleh Analis) }\end{array}$} & Keterangan \\
\cline { 1 - 5 } Kriteria & & & $\begin{array}{r}\text { Peringkat } \\
\text { (Prioritas) }\end{array}$ & $\begin{array}{c}\text { Nilai } \\
\text { (Prioritas) }\end{array}$ & $\begin{array}{c}\text { Keseluruhan } \\
\text { (Prioritas) }\end{array}$ & \\
\hline K. 1.1 & & & & & & \\
\hline K. 1.2 & & & & & & \\
\hline K. 1.3 & & & & & & \\
\hline
\end{tabular}




\subsubsection{Penghitungan bobot relatif}

Setelah para pakar dalam tim memberikan suatu peringkat dan nilai pada tiap elemen keputusan, respon mereka perlu dianalisis. Tujuan analisis ini adalah menghitung bobot atau kepentingan relatif setiap elemen keputusan berdasarkan sintesis dari beberapa respon berbeda yang diberikan.

Langkah 1: Setelah Tim Pakar mengisi formulir, data dapat dimasukkan ke dalam lembar isian atau tabel seperti Tabel 1. Tabel ini berisi data lapangan dari suatu tim pakar yang diminta untuk membuat Peringkat (menggunakan Peringkat Reguler) dan menetapkan nilai keempat Kriteria yang relevan dengan Prinsip 2 (Pemeliharaan Integritas Ekosistem) Pola Generik KEI CIFOR.

Tabel 1. Peringkat dan Nilai Kriteria yang Relevan dengan Prinsip 2

\begin{tabular}{|l|c|c|c|c|c|c|}
\hline \multicolumn{1}{|c|}{ Kriteria } & \multicolumn{2}{|c|}{ Pakar 1 } & \multicolumn{2}{c|}{ Pakar 2 } & \multicolumn{2}{c|}{ Pakar 3 } \\
\hline & Peringkat & Nilai & Peringkat & Nilai & Peringkat & Nilai \\
\hline K. 2.1 & 5 & 20 & 5 & 20 & 8 & 20 \\
\hline K. 2.2 & 8 & 40 & 7 & 35 & 8 & 30 \\
\hline K. 2.3 & 6 & 30 & 6 & 30 & 7 & 25 \\
\hline K. 2.4 & 4 & 10 & 4 & 15 & 6 & 15 \\
\hline & & & & & & \\
\hline
\end{tabular}

Langkah 2: Baik pada Penetapan peringkat maupun nilai, jumlahkan nilai yang diberikan para pakar untuk tiap Kriteria. Hasilnya adalah bobot total untuk tiap Kriteria dengan kedua teknik yang berbeda. Hitunglah nilai total Peringkat dan Nilai dari semua pakar. 
Tabel 2. Jumlah Nilai untuk Tiap Kriteria

\begin{tabular}{|l|c|c|c|c|}
\hline \multirow{2}{*}{ Kriteria } & \multicolumn{2}{|c|}{ Jumlah Peringkat } & \multicolumn{2}{c|}{ Jumlah Nilai } \\
\cline { 2 - 5 } & Perhitungan & Peringkat & Perhitungan & Nilai \\
\hline K. 2.1 & $5+5+8$ & 18 & $20+20+20$ & 60 \\
\hline K. 2.2 & $8+7+8$ & 23 & $40+35+30$ & 105 \\
\hline K. 2.3 & $6+6+7$ & 19 & $30+30+25$ & 85 \\
\hline K. 2.4 & $4+4+6$ & 14 & $10+15+15$ & 40 \\
\hline Total & & 74 & & 290 \\
\hline
\end{tabular}

Langkah 3: Agar dapat menggabungkan hasil teknik Penetapan peringkat dan Penetapan nilai pada Langkah 2, bobot relatif tiap Kriteria perlu dihitung untuk kedua teknik.

Bobot relatif tiap Kriteria dapat dihitung untuk tiap teknik dengan cara membagi bobot sebenarnya dengan bobot total sebenarnya dan kemudian dikalikan 100 .

\section{Tabel 3. Hasil Penghitungan Bobot Relatif untuk Teknik Penetapan Peringkat dan Penetapan Nilai}

\begin{tabular}{|l|c|c|c|c|}
\hline \multirow{2}{*}{ Kriteria } & \multicolumn{2}{|c|}{ Bobot Relatif } & \multicolumn{2}{c|}{ Bobot Relatif } \\
\cline { 2 - 5 } & Perhitungan & Peringkat & Perhitungan & Nilai \\
\hline K. 2.1 & $18 / 74 \times 100$ & 24 & $60 / 290 \times 100$ & 21 \\
\hline K. 2.2 & $23 / 74 \times 100$ & 31 & $105 / 290 \times 100$ & 36 \\
\hline K. 2.3 & $19 / 74 \times 100$ & 26 & $85 / 290 \times 100$ & 29 \\
\hline K. 2.4 & $14 / 74 \times 100$ & 19 & $40 / 290 \times 100$ & 14 \\
\hline Total & & 100 & & 100 \\
\hline
\end{tabular}


Setelah bobot relatif dari Peringkat dan Nilai dihitung, maka keduanya dapat dibandingkan. Pada kasus ini kedua teknik memperlihatkan hasil yang sama.

Langkah 4: Untuk menghitung bobot gabungan akhir bagi tiap Kriteria, bobot relatif hasil penghitungan Peringkat maupun Nilai dapat diambil rata-ratanya.

Tabel 4. Penghitungan Bobot Gabungan untuk Tiap Kriteria

Perhitungan Bobot Gabungan dari tiap Kriteria menunjukkan bahwa Kriteria

\begin{tabular}{|l|l|c|}
\hline \multicolumn{1}{|c|}{ Kriteria } & Perhitungan & Bobot Gabungan \\
\hline K. 2.1 & $(24+21) / 2$ & 22 \\
\hline K. 2.2 & $(31+36) / 2$ & 34 \\
\hline K. 2.3 & $(26+29) / 2$ & 28 \\
\hline K. 2.4 & $(19+14) / 2$ & 16 \\
\hline Total & & 100 \\
\hline
\end{tabular}

K. 2.1, K.2.2 dan K. 2.3 dianggap relatif lebih penting daripada Kriteria K. 2.4. Karena itu, mungkin akan sangat berguna untuk memeriksa kembali Kriteria K.2.4 untuk menentukan apakah kriteria tersebut dapat dihilangkan dari pertimbangan lebih lanjut dalam analisis.

Setelah melakukan penilaian bagi tiap Kriteria, maka Indikator pun dapat dinilai. Penilaian ini dilakukan dengan membuat Peringkat atau Nilai untuk Indikator menurut tingkat kepentingan relatifnya terhadap Kriteria di mana Indikator tersebut berada. 


\subsubsection{PEMBERIAN SKOR: LANGKAH KEDUA}

Sistem pemberian skor yang dapat mencerminkan kondisi sebuah UPH yang sedang dinilai merupakan kunci bagi semua sistem evaluasi. Metode AMK dapat digunakan untuk mengawali pemberian skor untuk mempersingkat set K\&I yang dievaluasi. Penyingkatan ini untuk memastikan agar waktu dan dana digunakan untuk menilai K\&I yang relevan saja.

Sementara proses pemberian skor untuk set K\&I yang berbeda berada di luar jangkauan panduan ini, di bawah ini disarankan suatu sistem pemberian skor yang dinamis dan informatif yang sesuai dengan AMK.

\begin{tabular}{|c|c|}
\hline Skor & Deskripsi Umum \\
\hline * & $\begin{array}{l}\text { Tidak mungkin memberi skor pada waktu penilaian; mungkin karena } \\
\text { kurangnya informasi atau tidak tersedianya sampel lapangan. Pemberian } \\
\text { skor ditunda sampai saat berikutnya. }\end{array}$ \\
\hline 0 & Tidak dapat diterapkan untuk Kriteria atau Indikator. \\
\hline 1 & Kondisi kinerja sangat buruk; sangat tidak baik. \\
\hline 2 & $\begin{array}{l}\text { Kondisi kinerja buruk; mungkin normal untuk wilayah tersebut, tetapi } \\
\text { diperlukan cukup banyak perbaikan. }\end{array}$ \\
\hline 3 & Dapat diterima; pada atau di atas normal untuk wilayah tersebut. \\
\hline 4 & $\begin{array}{l}\text { Kondisi sangat baik; jauh di atas normal untuk wilayah tersebut, tetapi } \\
\text { tetap memerlukan perbaikan untuk mencapai kondisi yang terbaik. }\end{array}$ \\
\hline 5 & $\begin{array}{l}\text { Kondisi yang terbaik bagi wilayah tersebut; kondisi sangat menonjol } \\
\text { dibandingkan standar normal untuk wilayah tersebut. }\end{array}$ \\
\hline
\end{tabular}




\subsubsection{PENILAIAN UNIT PENGELOLAAN HUTAN: LANGKAH KETIGA}

Ini merupakan langkah terakhir dalam penilaian K\&I. Sasaran langkah ini adalah memperkirakan kondisi UPH secara keseluruhan dan menyata-kannya dalam sebuah nilai. Perhitungan suatu nilai atau beberapa nilai yang dapat mencerminkan kondisi UPH tersebut memungkinkan kita untuk membandingkannya dengan UPH lainnya. Secara umum penilaian ini adalah penilaian yang paling mudah diterima jika dilakukan pada tingkat Kriteria karena cukup spesifik untuk memungkinkan adanya variasi, tetapi cukup umum sehingga memungkinkan pembandingan.

Nilai akhir tiap Kriteria dapat dihitung dengan mengambil rata-rata nilai 'bobot' yang diberikan pada seluruh Indikatornya. Nilai 'bobot' ini dapat dihitung dengan menggabungkan bobot relatif tiap Indikator (Langkah Pertama, Bab 3.3.2) dengan nilai sebenarnya yang diberikan pada tiap Indikator (Langkah Kedua, Bab 3.3.2). Dengan menggabungkan kedua langkah ini diperoleh satu nilai yang mencerminkan tingkat kepentingan relatif tiap Indikator dalam hubungannya dengan Kriteria yang dibantu pengukurannya. Pada Tabel 5 di bawah ini, Tim Pakar telah memberikan nilai untuk semua Indikator dalam Kriteria K. 2.1 dengan menggunakan metode Peringkat Reguler. Bobot Relatif tiap nilai telah dihitung, dan Bobot Relatif ini telah dirata-ratakan dengan mengikuti urutan perhitungan yang telah dijelaskan dalam Bab 3.3.1 'Pemilihan K\&I: Langkah Pertama'. Bobot Rata-rata ini telah dikombinasikan dengan nilai yang diberikan pada tiap Indikator untuk mendapatkan nilai yang telah dihitung. Jumlah nilai ini

Kriteria K. 2.1

Ada bukti yang jelas tentang hak-hak guna lahan hutan (misalnya, hak atas tanah, hak adat, atau persetujuan sewa) yang dapat diperlihatkan. 
merupakan skor akhir yang mencerminkan kondisi UPH dalam hubungannya dengan Kriteria K. 2.1.

Tabel 5. Penghitungan Skor Akhir untuk Kriteria K. 2.1

\begin{tabular}{|c|c|c|c|c|c|c|c|c|c|}
\hline \multirow{2}{*}{$\begin{array}{c}\text { Indikator } \\
2.1\end{array}$} & \multicolumn{3}{|c|}{ Peringkat } & \multicolumn{3}{|c|}{ Bobot Relatif } & \multirow{2}{*}{$\begin{array}{l}\text { Bobot } \\
\text { Rata-rata } \\
\text { (b) }\end{array}$} & \multirow{2}{*}{$\begin{array}{l}\text { Skor } \\
\text { (s) }\end{array}$} & \multirow{2}{*}{$\begin{array}{l}\text { Skor } \\
\text { Akhir } \\
\text { (b x s) }\end{array}$} \\
\hline & $\begin{array}{c}\text { Pakar } \\
1 \\
\end{array}$ & $\begin{array}{c}\text { Pakar } \\
2\end{array}$ & \begin{tabular}{|c} 
Pakar \\
3
\end{tabular} & \begin{tabular}{|c} 
Pakar \\
1
\end{tabular} & $\begin{array}{c}\text { Pakar } \\
2\end{array}$ & $\begin{array}{c}\text { Pakar } \\
3\end{array}$ & & & \\
\hline I. 2.1.1 & 7 & 9 & 7 & 27 & 27 & 26 & 27 & 3 & 80 \\
\hline I. 2.1.2 & 7 & 8 & 6 & 27 & 24 & 22 & 24 & 3 & 73 \\
\hline I. 2.1.3 & 6 & 8 & 8 & 23 & 24 & 30 & 26 & 2 & 51 \\
\hline I. 2.1.4 & 6 & 8 & 6 & 23 & 24 & 22 & 23 & 2 & 46 \\
\hline Total & 26 & 33 & 27 & 100 & 100 & 100 & & & 251 \\
\hline
\end{tabular}

Kolom Bobot Rata-rata memperlihatkan sedikit keragaman di antara nilai yang diberikan pada tiap Indikator. Sebagai hasilnya, semua Indikator ini penting dan harus digunakan dalam penilaian akhir UPH. Skor akhir untuk UPH dapat dihitung dengan mengambil jumlah Skor Akhir dan membaginya dengan 100. Dengan demikian skor akhir untuk Kriteria K. 2.1, berdasarkan penilaian Tim Pakar, adalah $(251 / 100)=2,51$.

Ukuran kinerja 2,51 secara tidak langsung menyatakan bahwa kinerja UPH agak rendah yang menurut patokan operasi regional dianggap baik berkenaan dengan Kriteria K. 2.1. Dengan kata lain, bukti-bukti adanya hak-hak guna hutan dan hak guna lahan belum dapat ditunjukkan. Menurut Pedoman Pemberian Skor pada Bab 3.3.2, skor 3 atau lebih besar Dapat Diterima: pada atau di atas normal untuk operasi yang baik di daerah tersebut. 


\section{Penerapan PHA yang Lebih Spesifik: Perbandingan Berpasangan}

\subsection{PERBANDINGAN BERPASANGAN}

Definisi: Metode Perbandingan Berpasangan (PB) meliputi perbandingan satu banding satu di antara tiap Indikator. Tim Pakar diminta untuk membuat penilaian banding tingkat kepentingan relatif tiap pasang Indikator yang berhubungan dengan Kriteria yang diukur. Penilaian ini digunakan untuk memberikan Bobot Relatif pada Indikator-indikator. Metode ini didasarkan pada tingkat Indikator karena pada tingkat ini beberapa Prinsip dan Kriteria paling mudah diukur dan diamati.

Kelebihan: Metode Perbandingan Berpasangan memberikan analisis yang jauh lebih baik bagi respon-respon yang diberikan Tim Pakar. Analisis ini lebih baik karena:

a. Seperti Penetapan Nilai, metode Perbandingan Berpasangan mengukur baik tingkat kepentingan ordinal maupun kardinal dari beberapa Indikator yang berbeda.

b. Respon-respon Tim Pakar sebaiknya lebih spesifik karena mereka harus mempertimbangkan tiap tingkat kepentingan Indikator yang berkaitan dengan semua Indikator lain.

c. Metode Perbandingan Berpasangan dapat dianalisis untuk konsistensi. Indeks Konsistensi dapat menunjukkan kapan terjadi ketidak-konsistenan yang besar di antara beberapa respon dan membantu menunjukkan dengan pasti di mana ketidak-konsistenan itu terjadi. Hal ini akan membantu menjadikan analisis lebih andal dan lebih tepat. 


\subsubsection{MENGUMPULKAN DATA}

Contoh: Untuk menghitung Bobot Relatif empat Indikator pada Kriteria K. 2.1 yang menggunakan metode Perbandingan berpasangan, Tim Pakar diberi Formulir Respon 2A (lihat Aneks 7.2). Dalam formulir ini mereka diminta untuk membandingkan tiap Indikator dengan ketiga Indikator lainnya yang relevan dengan Kriteria K. 2.1. Untuk memudahkan, mereka diminta menggunakan skala numerik berikut ini.

\begin{tabular}{|cl|}
\hline \multicolumn{2}{|c|}{ Skala Numerik untuk Penilaian Banding Beberapa Indikator } \\
\hline Skala & Arti/Penafsiran \\
\hline 1 & Sama Pentingnya \\
3 & Kepentingannya Agak Lebih \\
5 & Penting Sekali \\
7 & Sangat Penting Sekali \\
9 & Sangat Lebih Penting \\
\hline
\end{tabular}

Seorang pakar mungkin akan mengisi Formulir Respon 2A sebagai berikut,

\begin{tabular}{|c|c|c|c|c|c|c|c|c|c|c|c|c|c|c|c|c|c|}
\hline Indikator A & \multicolumn{16}{|c|}{ Kriteria K 2.1} & Indikator B \\
\hline I. 2.1 .1 & 9 & 8 & 7 & 6 & 5 & & 2 & 1 & & & 4 & 5 & & 67 & & 9 & I. 2.1 .2 \\
\hline I. 2.1 .1 & 9 & 8 & 7 & 6 & 5 & & 2 & 1 & & 2 & 4 & 15 & & $\begin{array}{lll}67 \\
\end{array}$ & 7 & 9 & I. 2.1 .3 \\
\hline I. 2.1 .1 & 9 & 8 & 7 & 6 & 5 & & 12 & 1 & & ? & 2 & $t$ & & 67 & & 9 & I. 2.1 .4 \\
\hline I. 2.1 .2 & 9 & 8 & 7 & 6 & 5 & & 2 & 1 & & & 4 & 5 & & 67 & & 9 & I. 2.1 .3 \\
\hline I. 1.1 .2 & 9 & 8 & 7 & 6 & 5 & & 2 & 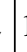 & & 2 & 2 & & & 67 & & 9 & I. 2.1.4 \\
\hline I. 1.1 .3 & 9 & 8 & 7 & 6 & 5 & 4 & 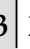 & & & 1 & 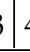 & & 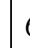 & $6 / 7$ & $?$ & 9 & I. 2.1.4 \\
\hline
\end{tabular}


Kotak yang berbayang merupakan kotak yang telah dipilih untuk mewakili hubungan di antara ke-2 Indikator yang dibandingkan.

Dari Perbandingan Berpasangan ini kita dapat membuat sebuah matriks perbandingan berikut:

\section{$\begin{array}{llll}\text { I. 2.1.1 } & \text { I. 2.1.2 } & \text { I. 2.1.3 } & \text { I. 2.1.4 }\end{array}$}

\begin{tabular}{ll|lll} 
I. 2.1 .1 & 1 & $1 / 6$ & $1 / 2$ & 2
\end{tabular}

I. $2.1 .2 \quad 6 \quad 1 \quad 1 / 2$

$\begin{array}{lllll}\text { I. } 2.1 .3 & 2 & 1 & 1 & 3\end{array}$

I. $2.1 .4 \quad 1 / 2 \quad 2 \quad 1 / 3 \quad 1$

Matriks ini merupakan suatu cara untuk menyajikan data yang dikumpulkan dengan menggunakan Formulir Respon 2A. Dengan menyajikan data yang membandingkan Indikator I. 2.1.1 sampai I. 2.1.4 dalam lembar matriks, maka penghitungan Bobot Relatif Kriteria 2.1 dapat dilakukan. Data dalam matriks dapat dijelaskan dengan menggunakan baris pertama sebagai sebuah contoh.

- Elemen pertama adalah 1 karena Indikator I. 2.1.1 dibandingkan dengan dirinya sendiri.

- Elemen kedua adalah 1/6 karena pakar menganggap I. 2.1.2 jauh lebih penting (nilai 6) dibandingkan I. 2.1.1. Karena itu nilai 1/6 ditempatkan pada persilangan baris I. 2.1.1 dan kolom I. 2.1.2, dan nilai 6 (berbanding terbalik) ditempatkan pada persilangan baris I. 2.1.2 dan kolom I. 2.1.1 (lihat kotak yang berbayang gelap).

- Elemen ketiga mempunyai nilai $1 \frac{1}{2}$ karena dalam membandingkan I. 2.1.1 dengan I. 2.1.3, pakar menganggap I. 2.1.3 sedikit lebih penting 
dibandingkan I. 2.1.1. Karena itu nilai 2 (berbanding terbalik dengan 1/2) ditempatkan pada persilangan baris I. 2.1.3 dan kolom I. 2.1.1 (lihat kotak yang lebih terang).

- Elemen keempat adalah 2 karena dalam membandingkan I. 2.1.1. dengan I. 2.1.4, pakar menganggap I. 2.1.1 sedikit lebih penting dibandingkan I. 2.1.4. Karena itu nilai $1 / 2$ (berbanding terbalik dengan 2) ditempatkan pada persilangan baris I. 2.1.4 dan kolom I. 2.1.1.

\subsubsection{MENGHITUNG BOBOT RELATIF}

Saaty (1995) menjelaskan empat pendekatan yang berbeda untuk menghitung Bobot Relatif berdasarkan matriks Perbandingan Berpasangan. Dalam panduan ini kami hanya akan menjelaskan satu di antara metode-metode yang kami anggap paling berguna dalam konteks penilaian K\&I. Untuk informasi mengenai metode lainnya dapat merujuk pada Saaty (1995).

Untuk menghitung Bobot Relatif Indikator-indikator dalam matriks seperti pada halaman terdahulu diperlukan tiga langkah.

Langkah 1: Hitung jumlah tiap kolom.

\section{2.1.1 $\quad$ I. 2.1.2 $\quad$ I. 2.1.3 $\quad$ I. 2.1.4}

\begin{tabular}{lllll} 
I. 2.1 .1 & 1 & $1 / 6$ & $1 / 2$ & 2 \\
I. 2.1 .2 & 6 & 1 & 1 & $1 / 2$ \\
I. 2.1 .3 & 2 & 1 & 1 & 3 \\
I. 2.1 .4 & $1 / 2$ & 2 & $1 / 3$ & 1 \\
\hline Total & 9,5 & 4,2 & 2,9 & 6,5
\end{tabular}


Langkah 2: Normalisasikan ${ }^{3}$ elemen-elemen dalam tiap kolom dengan membaginya dengan kolom total (yang dihitung dalam Langkah 1). Tambahkan elemen-elemen tiap baris yang dinormalisasi.

\section{$\begin{array}{llll}\text { I. 2.1.1 } & \text { I. 2.1.2 } & \text { I. 2.1.3 } & \text { I. 2.1.4 Total }\end{array}$}

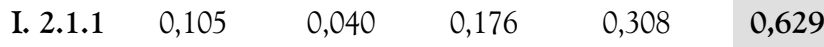

$(1 / 9,5)$

I. 2.1.2 0,632

$0,240 \quad 0,353 \quad 0,077 \quad 1,301$

$(6 / 9,5)$

I. 2.1.3 0,211

0,240

0,353

0,462

1,265

$(2 / 9,5)$

I. $2.1 .4 \quad 0,053$

0,480

0,118

0,154

0,804

$(0,5 / 9,5)$

\section{Intisari}

Angka-angka dalam tanda kurung memperlihatkan perhitungan yang digunakan untuk mendapatkan nilai yang disajikan dalam kotak. Misalnya, 1 dibagi (/) dengan $9,5($ kolom total $)=0,105$

Langkah 3: Bagi baris total pada Langkah 2 dengan jumlah Indikator yang dibandingkan. Dalam kasus ini empat Indikator dibandingkan.

Bobot Relatif I. 2.1.1: $\quad 0,629 / 4=0,1574$

Bobot Relatif I. 2.1.2: $\quad 1,301 / 4=0,3254$

Bobot Relatif I. 2.1.3: $\quad 1,265 / 4=0,3163$

Bobot Relatif I. 2.1.4: $\quad 0,804 / 4=0,2010$

Langkah 4: Hitung Bobot Relatif untuk Indikator-indikator berdasarkan masukan dari para pakar lainnya.

\footnotetext{
${ }^{3}$ Elemen-elemen perlu dinormalisasikan sehingga dapat dibandingkan dan diasimilasikan.
} 
Skor, yang diberi bayangan, yang dihitung di atas mewakili Bobot Relatif tiap Indikator berdasarkan Perbandingan Berpasangan dari satu pakar. Selanjutnya, perbandingan dari para pakar lainnya dalam tim perlu dimasukkan ke dalam lembar matriks dan diubah menjadi suatu nilai Bobot Relatif.

Dalam Uji Lapangan di Kalimantan Tengah, Bobot Relatif yang dihitung untuk para pakar lainnya adalah:

Tabel 6. Bobot Relatif Dihitung Menggunakan Perbandingan Berpasangan untuk Empat Pakar

\begin{tabular}{|c|c|c|c|c|c|}
\hline \multirow{2}{*}{ Indikator } & \multicolumn{4}{|c|}{ Perbandingan berpasangan } & \multirow{2}{*}{$\begin{array}{c}\text { Bobot Relatif } \\
\text { Rata-rata } \\
\text { (Total/4) }\end{array}$} \\
\cline { 2 - 5 } & $\begin{array}{c}\text { Pakar } \\
1\end{array}$ & $\begin{array}{c}\text { Pakar } \\
2\end{array}$ & $\begin{array}{c}\text { Pakar } \\
3\end{array}$ & $\begin{array}{c}\text { Pakar } \\
4\end{array}$ & 21 \\
\hline I. 2.1 .1 & 16 & 52 & 7 & 11 & 22 \\
\hline I. 2.1.2 & 33 & 9 & 14 & 30 & 38 \\
\hline I. 2.1.3 & 32 & 13 & 54 & 51 & 20 \\
\hline I. 2.1.4 & 20 & 26 & 25 & 8 & \\
\hline
\end{tabular}

Perhatikan bahwa semua skor ini telah dikalikan 100. Misalnya, skor yang diberikan pada I. 2.1.1 oleh pakar 1 dalam perhitungan di atas adalah 0,1574, dan dalam Tabel 6 telah dibulatkan dan dikalikan 100 untuk mendapatkan skor 16. Cara ini dilakukan agar angka-angka lebih mudah dihitung. Selama semua angka dikalikan 100, hubungan di antaranya tidak akan berubah.

Langkah 5: Hitung skor akhir untuk Kriteria K. 2.1.

Seperti halnya pada pendekatan Penetapan peringkat dan Penetapan nilai, Bobot Relatif Rata-rata yang dihitung untuk tiap Indikator dapat digabung- 
kan dengan skor yang diberikan oleh tiap Indikator untuk memunculkan suatu skor yang bobotnya terhitung untuk tiap Indikator. Jumlah skor yang telah dihitung untuk indikator ini memberikan sebuah skor akhir yang bobotnya terhitung untuk Kriteria yang sedang dibicarakan (K. 2.1).

\begin{tabular}{|c|c|c|c|}
\hline Indikator & $\begin{array}{c}\text { Bobot Relatif } \\
\text { Rata-rata } \\
\text { (b) }\end{array}$ & $\begin{array}{c}\text { Skor } \\
(\mathrm{s})\end{array}$ & $\begin{array}{c}\text { Skor yang } \\
\text { Bobotnya } \\
\text { Terhitung (b x s) }\end{array}$ \\
\hline I. 2.1.1 & 21 & 3 & 63 \\
\hline I. 2.1.2 & 22 & 3 & 66 \\
\hline I. 2.1.3 & 38 & 2 & 76 \\
\hline I. 2.1.4 & 20 & 2 & 40 \\
\hline Total & & & 245 \\
\hline
\end{tabular}

Skor Akhir Penghitungan K. 2.1

Skor akhir yang menggunakan Perbandingan Berpasangan adalah $(245 / 100)=2,45$.

Skor akhir yang menggunakan metode Penetapan peringkat adalah 2,51.

Kotak ringkasan di atas menyajikan skor akhir yang dihitung untuk UPH dan yang dibicarakan dengan menggunakan pendekatan Perbandingan berpasangan, dan pendekatan Penetapan peringkat yang lebih sederhana. Dalam kasus ini kedua skor hampir sama dan dengan demikian kelebihan utama penggunaan Perbandingan berpasangan adalah kemudahannya untuk menganalisis konsistensi penilaian yang dibuat oleh tiap pakar. Cara menghitung Indeks Ketidak-konsistenan ini dijelaskan dalam bagian selanjutnya. 


\subsection{MENGHITUNG INDEKS KETIDAK-KONSISTENAN (I.K.) ${ }^{4}$}

Indeks Ketidak-konsistenan (I.K.) adalah suatu alat pengukur untuk mengetahui seberapa besar penilaian para pakar/partisipan konsisten secara logis. Skenario berikut memberikan satu contoh ketidak-konsistenan suatu penilaian.

\begin{tabular}{|l|}
\hline Skenario Perbandingan Berpasangan \\
\hline Kegunaan : untuk memberikan satu contoh ketidak-konsistenan penilaian \\
Skenario : Seorang pakar diminta mengerjakan Perbandingan Berpasangan untuk \\
\\
3 indikator yang disebut a, b dan c. Ia menentukan bahwa Indikator \\
a lebih penting daripada indikator b dengan nilai 3; Indikator b lebih \\
penting daripada Indikator c dengan nilai 3; Indikator c dan Indikator \\
a sama pentingnya. \\
Analisis : Dalam skenario ini keputusan pakar untuk memberikan indikator a \\
dan b pada tingkat kepentingan yang sama adalah tidak konsisten. \\
Berdasarkan perbandingan sebelumnya, suatu penilaian yang konsisten \\
secara logis akan menentukan bahwa indikator a lebih penting daripada \\
Indikator c dengan nilai 6. Ketidak-konsistenan ini terjadi karena \\
berbagai alasan, misalnya interpretasi individu terhadap indikator, \\
kelelahan dan sifat metodologi yang berulang-ulang.
\end{tabular}

Oleh karena itu dalam skenario, sangat berguna bagi analisis untuk memiliki cara untuk mengukur konsistensi penilaian yang diberikan. Secara umum konsistensi penilaian yang lebih tinggi secara tidak langsung menyatakan penilaian yang lebih baik dan oleh karena itu akan menghasilkan perkiraan bobot yang lebih dapat dipercaya.

4 Indeks Ketidak-konsistenan umumnya disebut sebagai Indeks Konsistensi; karenanya disingkat I.K. Walaupun demikian, dalam konteks panduan ini, apabila istilah I.K. digunakan maka merujuk kepada pengukuran ketidak-konsistenan. 
Indeks Ketidakkonsistenan memberikan satu cara untuk mengukur konsistensi penilaian suatu Tim Pakar pada saat mereka menggunakan metode Perbandingan Berpasangan. Pengukuran ini akan menyediakan informasi mengenai konsistensi yang berkenaan dengan tingkat kepentingan ordinal maupun kardinal dari dua elemen yang dibandingkan. Secara umum, toleransi indeks konsistensi sebesar 10\% ditentukan dalam perbandingan yang melibatkan tidak lebih dari 9 elemen. Karena jarang terjadi ada lebih dari 9 Indikator dalam suatu Kriteria, tingkat toleransi ini adalah yang paling dapat diterapkan pada analisis K\&I. Tingkat ketidak-konsistenan yang lebih tinggi barangkali dapat ditoleransi untuk perbandingan yang melibatkan lebih dari 9 elemen.

Dengan menggunakan set Indikator dalam Kriteria K. 2.1 kita dapat menghitung Indeks Ketidak-konsistenan sebagai berikut:

Langkah 1: Kalikan kolom total dari tiap Indikator (lihat Bab 4.1.2 Penghitungan Bobot Relatif: Langkah 1) dengan bobot relatif terhitung dari tiap Indikator (lihat Bab 4.1.2 Penghitungan Bobot relatif: Langkah 3), dan tambahkan hasilnya.

Dengan menggunakan Indikator-indikator untuk Kriteria K. 2.1, hasilnya akan menjadi,

$(9,5 \times 0,1574)+(4,17 \times 0,3254)+(2,83 \times 0,3163)+(6,50 \times 0,2010)=5,054$

Langkah 2: Kurangkan jumlah elemen (Indikator-indikator yang dibandingkan) pada hasil Langkah 1.

$5,054-4=1,054$ 
Langkah 3: Bagi hasil Langkah 2 dengan jumlah Indikator dikurangi satu.

$1,054 /(4-1) \cong 0,35$

Karena itu Indeks Konsistensi untuk matriks ini adalah 0,35 atau 35\%. Karena angka ini di atas toleransi Indeks Konsistensi 10\%, secara tidak lang-sung menyatakan derajat ketidak-konsistenan yang tinggi antara penilaian pakar yang memberikan respon. Dalam konteks analisis, respon-respon ini mungkin tidak memberikan suatu perkiraan bobot relatif Indikator yang sangat dapat dipercaya.

\subsection{MENINGKATKAN KONSISTENSI PENILAIAN (BAGI TIAP PAKAR)}

Sementara bagi analisis sangat penting untuk dapat mengukur derajat ketidak-konsistenan yang berhubungan dengan penilaian individu dalam Tim Pakar, pengukuran ini sendiri tidak akan membantu memperbaiki konsistensi penilaian-penilaian ini. Salah satu kelebihan metode Perbandingan berpasangan adalah bahwa metode ini memungkinkan untuk mengetahui dengan pasti keputusan yang memberikan andil pada ketidak-konsistenan dalam penilaian yang dibuat oleh tiap pakar. Dengan informasi mengenai hal-hal spesifik ketidak-konsistenan, Tim Pakar memiliki perangkat untuk melakukan evaluasi kembali kumpulan respon yang pertama dibuat, dan memodifikasinya supaya menjadi lebih konsisten.

Untuk Indikator dalam Kriteria K. 2.1., matriks perbandingan yang mewakili respon-respon pakar 1 seperti berikut ini (untuk penjelasan lebih terinci mengenai cara penghitungan Bobot Relatif lihat Penghitungan Bobot Relatif): 


$\begin{array}{llllll} & \text { I. 2.1.1 } & \text { I. 2.1.2 } & \text { I. 2.1.3 } & \text { I. 2.1.4 } & \text { Bobot Relatif } \\ \text { I. 2.1.1 } & 1 & 1 / 6 & 1 / 2 & 2 & 0,1574 \\ \text { I. } 2.1 .2 & 6 & 1 & 1 & 1 / 2 & 0,3254 \\ \text { I. } 2.1 .3 & 2 & 1 & 1 & 3 & 0,3163 \\ \text { I. } 2.1 .4 & 1 / 2 & 2 & 1 / 3 & 1 & 0,2010\end{array}$

Indeks Konsistensi yang dihitung dalam Bagian terdahulu untuk matriks ini $\cong 35 \%$. Langkah selanjutnya adalah mencoba dan menentukan dengan pasti sumber ketidak-konsistenan yang tinggi ini. Agar dapat melakukannya, konsistensi tiap perbandingan yang dibuat perlu dihitung. Dalam matriks di atas ini berarti tiap nilai yang diberi bayangan sebaiknya dianalisis. Hanya sebagian matriks yang perlu dianalisis karena nilai-nilai dalam sebagian bidang yang berbayang adalah nilai kebalikan dari sebagian yang tidak berbayang. Dengan kata lain, nilai-nilai pada sebagian bidang yang berbayang mewakili perbandingan yang sama, hanya dengan cara yang berlawanan.

Untuk setiap perbandingan suatu nilai yang mencerminkan ketidakkonsistenan penilaian dapat dihitung dengan mengalikan nilai yang diberikan dengan rasio bobot relatif (b1/b2) dua Indikator yang dibandingkan.

Misalnya, nilai yang diberikan berkaitan dengan I. 2.1.1 dan I. 2.1.2 adalah $1 \%$. Untuk menghitung suatu nilai ketidak-konsistenan bagi perbandingan ini, 1/6 harus dikalikan dengan rasio bobot relatif I. 2.1.1 $(0,1574)$ dan I. 2.1.2 (0,3254). Perhitungannya menjadi, $1 / 6 \times(0,1574 / 0,3254)=0,08$

Dengan menggunakan perhitungan ini, matriks berikut dapat disusun. Bidang yang berbayang menunjukkan cara penghitungan tiap nilai ketidakkonsistenan. 


\section{$\begin{array}{llll}\text { I. } 2.1 .1 & \text { I. } 2.1 .2 & \text { I. } 2.1 .3 & \text { I. } 2.1 .4\end{array}$}

$\begin{array}{lllll}\text { I. } 2.1 .1 & 1 & 0,08 & 0.25 & 1.57\end{array}$

I. 2.1 .2

$1 / 6(0,157 / 0,325)$

$1 / 2(0,157 / 0,316) \quad 2(0,157 / 0,201)$

$2.1 .2-1$

$1,03 \quad 0,81$

$1(0,325 / 0,316) \quad 1 / 2(0,325 / 0,201)$

I. 2.1.3

1

4,72

$3(0,316 / 0,201)$

I. 2.1.4

Perbandingan dengan nilai terhitung terendah adalah yang paling tidak konsisten.

Penafsiran: Dalam matriks di atas perbandingan dengan nilai terhitung terendah adalah perbandingan antara I. 2.1.1 dan I. 2.1.2 (0,08). Karena itu merupakan perbandingan yang paling tidak konsisten yang dibuat oleh pakar 1 .

Untuk memperbaiki konsistensi penilaian yang dibuat oleh pakar ini, Perbandingan Berpasangan dari I. 2.1.1 dan I. 2.1.2 sebaiknya diubah menjadi rasio Bobot Relatif $\left(b_{1} / b_{2}\right)$. Ingat bahwa $1 / 6$ berarti pakar 1 yang menilai I. 2.1.2 enam kali lebih penting daripada I. 2.1.1. Dalam kasus ini rasio Bobot Relatif (b1/b2) adalah $(0,157 / 0,325)$. Agar dapat menafsirkan rasio ini secara bermanfaat, rasio tersebut perlu diubah menjadi format $1 / x$. Di mana,

$0,325 \div 0,157=2,07$

rasio 0,157/0,325 kurang lebih dinyatakan sama dengan 1/2. Karena itu untuk mengurangi ketidak-konsistenan penilaian pakar 1, nilai $1 / 6$ perlu digeser lebih dekat ke nilai 1/2. Dengan kata lain, I. 2.1.2 sebaiknya dinilai sebagai yang lebih penting daripada I. 2.1.1 dengan nilai 2, bukan 6 . 


\begin{tabular}{|c|c|c|c|c|c|c|c|c|c|c|c|c|c|c|c|c|}
\hline $\begin{array}{c}\text { Indika- } \\
\text { tor A }\end{array}$ & \multicolumn{15}{|c|}{ Kriteria K. 2.1} & $\begin{array}{l}\text { Indika- } \\
\text { tor } B\end{array}$ \\
\hline I. 2.1.1 & 9 & 8 & 7 & 6 & 5 & 4 & 3 & 2 & 2 & 3 & 4 & 5 & 7 & \begin{tabular}{|l|}
8 \\
\end{tabular} & 9 & I. 2.1 .2 \\
\hline
\end{tabular}

Perubahan nilai ini akan mengubah Bobot Relatif Indikator dan Indeks Ketidakkonsistenan pakar 1 akan menjadi 0,38. Proses ini dapat diulang sampai I.K. berada dalam tingkat toleransi 10\%. Sasarannya bukan untuk menghilangkan ketidak-konsistenan secara total, tetapi untuk membuatnya berada dalam batas toleransi. 


\section{Pendekatan Bottom-up dan Pengelolaan Hutan}

Pendekatan 'Bottom-up' pada seleksi K\&I berbeda dari pendekatan 'Topdown' dalam hal-hal berikut ini:

- Pendekatan 'Bottom-up' dapat digunakan untuk memilih suatu set K\&I tanpa harus memanfaatkan Pola Generik. Dalam kasus ini set K\&I yang dipilih berasal dari ide dan rekomendasi Tim Seleksi.

- Dilihat dari perspektif sertifikasi hutan, fokus yang diberikan dalam penilaian K\&I sangat sedikit. Sebaliknya, perhatian diberikan pada penilaian K\&I sebagai perangkat pengelolaan dalam konteks Pengelolaan Hutan Lestari secara umum.

- Pendekatan sengaja disusun dengan cara yang memungkinkan keterlibatan langsung dan partisipasi aktif berbagai stakeholder dalam Unit Pengelolaan Hutan.

Suatu penerapan teoritis pendekatan 'Bottom-up' diuraikan dalam kotak di bawah ini.

\section{Skenario Pengelolaan Hutan \\ Pendekatan Bottom-Up}

Langkah 1 Adakan sesi curah pendapat. Tiap anggota Tim berhak untuk memberi saran tentang daftar K\&I yang tepat.

Langkah 2 Sebuah daftar lengkap berisi semua K\&I yang disarankan disusun.

Langkah 3 Tiap Anggota Tim diminta mengambil sebuah angka (n) Kriteria atau Indikator tertentu dari daftar. Angka ini dapat bervariasi tergantung pada sumber daya atau keragaman dalam UPH yang bersangkutan. 
Langkah 4 Anggota Tim diminta membuat peringkat bagi Kriteria atau Indikator dalam daftar mereka menurut derajat tingkat kepentingan yang dirasakan (misalnya $1,2, \ldots \mathrm{n})$.

Langkah 5 Dari daftar peringkat yang disusun oleh tiap anggota Tim dalam Langkah 4, tentukan bobot relatif tiap Kriteria dan Indikator.

Langkah 6 Prioritaskan dan pilih K\&I berdasarkan bobot relatifnya. K\&I yang secara nyata telah dinilai lebih rendah dapat disingkirkan.

Langkah 7 Jika daftar tersebut memuaskan seluruh anggota Tim dan dapat diterima maka kemudian diidentifikasi. Jika tidak, proses dapat diulang dengan menambah (n), atau dengan mempertimbangkan K\&I lainnya dari daftar lengkap yang semula dimasukkan.

\subsection{STUDI KASUS: KALIMANTAN TENGAH}

\section{Intisari}

Informasi dalam pendekatan 'Bottom-up' disajikan pada bagian ini dalam satu format studi kasus. Butir kunci yang tercakup dalam studi ini diuraikan dalam suatu kotak teks pada akhir Bagian ini.

Agar dapat menjelaskan penerapan pendekatan Bottom-up, sebuah studi kasus yang dikerjakan di Kalimantan Tengah (Mendoza dan Prabhu. 1998b) diuraikan di bawah ini. Studi ini bukan merupakan pendekatan Bottom-up yang murni menurut Pola Generik CIFOR yang digunakan sebagai panduan. Tim Penilai bebas menambah/menghilangkan atau menciptakan K\&I, tetapi mereka tidak memulai dari 'awal'. Sasaran mereka adalah menciptakan suatu set K\&I yang sesuai sebagai satu panduan bagi Pengelolaan Hutan dalam UPH yang sedang diteliti. Dalam beberapa hal, ini merupakan satu contoh yang baik dari pendekatan 'kombinasi' yang menggabungkan aspek-aspek pendekatan Topdown dan Bottom-up. Walaupun demikian, dalam bagian ini Studi Kasus 
digunakan untuk menjelaskan kelebihan dan kesulitan penggunaan AMK dalam situasi Bottom-up.

Penilaian K\&I dilaksanakan dalam suatu UPH yang luasnya kira-kira 125.000 hektar dan mulai beroperasi pada tahun 1973. Laporan tahunan perusahaan pada tahun 1997 memper-

\section{Tim Penilai yang Dibentuk}

- 4 orang pegawai; staf UPH penuh waktu

- 2 orang penduduk desa berasal dari 2 desa di dalam program kehutanan masyarakat UPH

- 1 orang dosen

- 1 orang pegawai pemerintah

- 1 orang ilmuwan sosial

- 1 orang pegawai CIFOR yang tinggal di lokasi

lihatkan hasil sekitar 94.800 meter kubik 2.200 hektar wilayah HPH. Semua hasil kayu dikirimkan ke pabrik pemrosesan kayu, terutama pabrik kayu lapis. Ada lima desa dan kawasan pemukiman, serta tiga daerah trans-migrasi yang berlokasi dalam wilayah $\mathrm{HPH}$.

Sebuah Tim Penilai, yang cukup mewakili berbagai stakeholder dalam UPH, telah dibentuk. Proses penentuan stakeholder dan pelibatannya dalam proses pengambilan keputusan, merupakan tugas yang kompleks dan sulit. Referensi lebih lanjut dalam identifikasi stakeholder dicantumkan pada akhir Bagian ini.

Mengetahui adanya kesenjangan keahlian, latar belakang pendidikan dan kemampuan teknik dari anggota tim, maka perlu dilakukan diskusi dan presentasi mengenai K\&I dan AMK sebelum pemungutan suara dilakukan. Setengah hari disisihkan untuk diskusi/presentasi ini; prosedur di bawah inilah yang digunakan:

- K\&I Generik diterjemahkan ke dalam bahasa daerah.

- Diskusi, pertanyaan dan interaksi dilakukan dalam bahasa daerah. 
- Formulir respon disiapkan dan diterjemahkan terlebih dahulu.

- Penjelasan dokumen secara singkat menerangkan K\&I, pada umumnya, dan AMK, pada khususnya, juga disiapkan dan diterjemahkan terlebih dahulu.

- Instruksi umum dalam pengisian formulir dijelaskan sepenuhnya.

\section{PROSES PEMUNGUTAN SUARA}

Untuk memudahkan proses pemungutan suara, 10 orang anggota tim dibagi menjadi dua subkelompok. Kelompok 1 terdiri dari anggota-anggota yang mempunyai keahlian yang berhubungan dengan Prinsip Kebijakan dan Sosial; Kelompok 2 terdiri dari anggota-anggota yang mempunyai keahlian yang berhubungan dengan Prinsip Ekologi dan Produksi.

Sebelum pemungutan suara dimulai, fasilitator AMK memberi penjelasan tentang:

- Elemen K\&I (sebagai contoh Prinsip, Kriteria, Indikator) yang dievaluasi.

- Hubungan hierarki antara elemen yang dievaluasi.

- Peran teknik-teknik AMK.

- Tipe masukan yang diperlukan dari para anggota tim tergantung teknik AMK yang digunakan.

- Instruksi untuk mengisi formulir respon.

Kronologi analisis yang dijalankan sebagai berikut:

1. Analisis tingkat Kriteria dilakukan lebih dulu. Dalam cara ini, para anggota tim diperkenalkan pada analisis yang tingkat perinciannya cukup dalam dan luas sehingga mudah dipahami para anggota tim.

2. Analisis tingkat Indikator mengikuti penilaian Kriteria. Pada tahap ini tampaknya tiap anggota tim telah memperoleh suatu pengertian yang 
lebih baik tentang proses dan K\&I. Lebih penting lagi, ini merupakan tingkat di mana para anggota tim mungkin merasa paling nyaman karena Indikator tidak terlalu konseptual dan lebih terinci dibandingkan Prinsip dan Kriteria.

3. Penilaian pada tingkat Prinsip dilakukan setelah analisis tingkat Kriteria dan Indikator. Dengan menganalisis tingkat Prinsip terakhir, maka para anggota tim diharapkan akan sangat mengetahui proses K\&I dan AMK, dan akan lebih siap melakukan penilaian yang lebih luas dan dibutuhkan pada tingkat Prinsip. Pada tingkat ini, tim tidak dibagi dalam subkelompok.

Seperti dalam pendekatan Top-down, pemungutan suara disusun sedemikian rupa sehingga tiap Kriteria atau Indikator didiskusikan dalam sebuah kelompok, tetapi setiap orang memilih secara individual. Setiap subkelompok juga memilih salah satu anggota untuk memudahkan diskusi.

Pendekatan Penetapan peringkat dan Penetapan nilai digunakan sebagai perangkat penyaringan awal. Teknik ini memungkinkan cara yang cepat untuk menyaring elemen-elemen K\&I yang tidak cukup penting. Perbandingan Berpasangan digunakan sebagai saringan halus untuk menentukan lebih lanjut di mana elemen-elemen K\&I kurang penting dan mungkin dianjurkan untuk dihapus. Tim tampaknya paling senang dengan Perbandingan Berpasangan, terutama karena banyaknya penilaian satu banding satu yang perlu dibuat. Ini mungkin disebabkan karena Perbandingan Berpasangan dilakukan pada akhir penilaian di mana tim lelah dan kurang dapat memusatkan perhatian. 


\section{Butir-butir Kunci}

Sejumlah butir kunci dapat diekstrapolasi kemungkinannya dari pengalamanpengalaman di Kalimantan Tengah dan diterapkan pada pendekatan Bottom-up atau 'Kombinasi' untuk penilaian K\& I.

1. Membentuk satu Tim Seleksi dengan gambaran yang sesuai dari stakeholder yang berbeda sangat diperlukan dalam UPH. Sifat dasar Tim Seleksi akan sangat mempengaruhi kemampuan penerapan dan penerimaan umum suatu keputusan yang telah dibuat.

2. Waktu yang cukup harus disediakan untuk persiapan. Ini mungkin termasuk menerjemahkan semua dokumen yang relevan ke dalam bahasa daerah, juga pelaksanaan diskusi dan lokakarya agar Tim Seleksi terbiasa dengan K\&I dan AMK.

3. Tehnik-teknik AMK yang digunakan harus relevan dengan sasaran analisis.

4. Waktu yang cukup harus disediakan untuk proses. Idealnya perlu disediakan waktu bagi Tim Seleksi untuk beristirahat di antara proses analisis Penetapan peringkat/Penetapan nilai dan Perbandingan berpasangan.

5. Dengan adanya seorang fasilitator dalam tiap subkelompok akan membantu memastikan semua anggota tim terlibat dalam proses diskusi.

\section{Rujukan untuk Identifikasi Stakeholder}

Borrini-Feyerabend, G. (ed.). 1997. Beyond Fences: Seeking Social Sustainability in Conservation, Volume 1 and 2. IUCN, Gland, Switzerland.

Colfer, C. J.P., Brocklesby, M.A., Diaw, C., Etuge, P., Günter, M., Harwell, E., McDougall, C., Porro, N.M., Porro, R., Prabhu, R., Salim, A., Sardjono, M.A., Tchikangwa, B., Tiani, A.M., Wadley, R.L., Woelfel, J. dan Wollenberg, E. 1999. The Bag (Basic Assessment Guide for Human well-Being). Criteria \& Indicators Toolbox Series No. 5. CIFOR, Bogor, Indonesia. 


\section{Daftar Pustaka dan Bacaan Lebih Lanjut}

Forest Stewardship Council (FSC). 1994. Forestry Stewardship Principles and Criteria for Natural Forest Management. Oaxaca, Mexico.

Golden, B., P. Harker dan E. Wasil. 1989. The Analytic hierarchy Process: Applications and Studies. Springer Verlag, the Netherlands.

International Timber Trade Organization (ITTO). 1992. Critria for the measurement of sustainable tropical forest management, Yokohama, Japan.

Landres, P.B. 1992. Ecological indicators: Panacea or liability? Dalam: McKenzie, D.H., Hyatt, D.E. dan McDonald, J.E. (ed.) Ecological Indicators, Volume 2, hal. 1295-1319. Elsevier Applied Science, London.

Mendoza, G.A. 1997a. Introduction to the Analytic Hierarchy Process: Theory and Application to Natural Resources Management. Proceedings: Joint Annual Meeting of the American Congress on Surveying and Mapping (ACSM); American Association of Photogrammetry and Remote Sensing (ASPRS), and Resources Technology Institute (RTI). April 5-10. Seattle, WA.

Mendoza, G.A. 1997b. A GIS-based Multicriteria approaches to land suitability assessment and allocation. Proceedings: Seventh International Symposium on Systems Analysis in Forest Resources. May 28 -31. Traverse City Michigan.

Mendoza, G.A. dan R. Prabhu. 1998a. Multiple Criteria Decision Making Approaches to Assessing Forest Sustainability Using Criteria and Indikators: A Case Study - Part I. CIFOR, Bogor, Indonesia. 
Mendoza, G.A. dan R. Prabhu. 1998b. Multiple Criteria Analysis for Assessing Criteria and Indikators in Sustainable Forest Management: A Case Study on Participatory Decision Making - Part II. CIFOR, Bogor, Indonesia.

Oxford Dictionary of Current English. 1987. Oxford University Press, New York.

Prabhu, R., C.J.P. Colfer, P. Venkateswarlu, L.C. Tan, R. Soekmadi, dan E. Wollenberg. 1996. Testing Criteria and Indikators for the sustainable management of forests. Phase I. Final Report. CIFOR Special Publication. CIFOR, Bogor, Indonesia.

Prabhu, R., C.J.P. Colfer, dan R.G. Dudley. 1999. Guidelines for Developing, Testing and Selecting Criteria and Indikators for Sustainable Forest Management. Criteria and Indicators Toolbox Series No. 1. CIFOR, Bogor, Indonesia.

Saaty, T. 1995. Decision making for leaders: The Analytic Hierarchy Process in a complex world. RWS Publications, Pittsburgh, PA.

Scientific Certification Systems (SCS). 1994. The Forest Conservation Program: Programme Description and Operations Manual. SCS, California.

SGS Forestry. 1994. Assessors Handbook, Policy Document and Procedures Manual. SGS Forestry, Oxford, UK.

Tropenbos Foundation. 1997. Hierarchical Framework for the formulation of sustainable forest management standards. Tropenbos, The Netherlands.

Vargas, L. dan F. Zahedi. 1993. Special Issue. Analytic Hierarchy Process and its applications. Mathematical and Computer Modeling. Vol 17. 


\section{Aneks}

\subsection{GLOSARI}

\begin{tabular}{|l|}
\hline Analisis Multikriteria (AMK) \\
Suatu perangkat pengambilan \\
keputusan yang dikembangkan untuk \\
masalah-masalah multikriteria yang \\
kompleks dan mungkin meliputi aspek \\
kualitatif dan kuantitatif dari masalah \\
dalam proses pengambilan keputusan. \\
\hline
\end{tabular}

\section{Elemen Keputusan}

Istilah ini merupakan suatu referensi umum untuk elemen-elemen berbeda yang perlu dianalisis agar dapat membuat keputusan yang kompleks.

\section{Indeks Ketidak-konsistenan (I.K.)}

Pengukuran konsistensi penilaian suatu Tim Pakar pada saat mereka menggunakan metode Perbandingan berpasangan. I.K. dapat memberikan informasi mengenai konsistensi dalam hal tingkat kepentingan ordinal dan kardinal dari dua elemen yang dibandingkan.

\section{Indikator}

Suatu indikator dapat berupa suatu peubah atau komponen ekosistem hutan atau sistem pengelolaan yang digunakan untuk menyimpulkan ciriciri kelestarian suatu sumber daya dan pemanfaatannya (Landres 1992; Prabhu dkk. 1996).

\section{Kriteria}

Kriteria merupakan suatu titik tengah di mana informasi yang disediakan dari indikator dapat diintegrasikan dan cara penilaian yang dapat ditafsirkan menjadi semakin jelas (Prabhu dkk. 1999).

\section{Pembobotan}

Suatu nilai yang mencerminkan tingkat kepentingan relatif suatu elemen keputusan (misalnya Indikator) dengan mempertimbangkan elemen keputusan lainnya. 


\section{Penetapan Nilai}

Elemen-elemen keputusan diberi 'skor' antara 0 dan 100 . Skor untuk semua elemen yang dibandingkan harus mencapai 100.

\section{Penetapan Peringkat}

Tiap elemen keputusan diberi peringkat yang mencerminkan derajat

kepentingan relatif yang dapat dilihat terhadap keputusan yang dibuat. Elemen keputusan kemudian dapat diurutkan menurut peringkatnya (pertama, kedua, dst).

\section{Pengelolaan Hutan Lestari}

Cara-cara pengelolaan hutan dengan tetap mempertahankan atau bahkan meningkatkan berbagai fungsi ekologis hutan dan kesejahteraan manusia.

\section{Pengukur (verifier)}

Data atau informasi yang lebih spesifik sehingga meningkatkan kemudahan untuk melakukan penilaian terhadap indikator (Prabhu dkk. 1996).

Perbandingan berpasangan

Membuat perbandingan satu banding satu di antara tiap elemen keputusan (misalnya, Indikator).

Prinsip

Adalah suatu kebenaran atau aturan mendasar yang digunakan sebagai landasan berpikir atau bertindak (Oxford Dictionary of Current English 1987, Prabhu dkk. 1999).

\section{Proses Hierarki Analitik (PHA)}

Metode PHA mengurangi keputusankeputusan kompleks menjadi satu rangkaian perbandingan sederhana, yang disebut Perbandingan berpasangan, di antara elemen-elemen hierarki keputusan. Dengan mensintesis hasil perbandingan ini, PHA dapat membantu mencapai keputusan terbaik dan memberikan alasan yang jelas bagi pilihan yang Anda buat.

\section{Tingkat Kepentingan Kardinal}

Istilah ini berhubungan dengan perbedaan yang besar di antara tingkat kepentingan dua elemen. Sebagai contoh, satu elemen mungkin tiga kali lebih penting daripada yang lainnya.

\section{Tingkat Kepentingan Ordinal}

Istilah ini berhubungan dengan urutan tingkat kepentingan dari daftar elemen yang terlibat. Sebagai contoh, mana yang datang pertama, kedua, dst.

\section{Stakeholder}

Pihak-pihak perorangan atau kelompok yang memiliki kepentingan terhadap hutan.

\section{Unit Pengelolaan Hutan (UPH)}

Suatu lahan yang memiliki batas-batas yang jelas, terutama tertutup oleh hutan, dan dikelola sesuai dengan sasaran yang jelas dan sesuai dengan suatu rencana pengelolaan jangka panjang. 


\subsection{LEMBAR PENGUMPULAN SAMPEL DATA}

\section{Formulir Respon 1A}

(Silakan merujuk pada Pola Generik CIFOR untuk Informasi Terinci mengenai Prinsip)

Deskripsi: Formulir Respon 1A dirancang untuk Analisis Tingkat 1 pada Tahap1. Tahap1 bertujuan menghasilkan suatu daftar prioritas Kriteria berdasarkan Pola Generik KEI CIFOR. Dari analisis Tingkat 1 diperoleh respon dari responden berdasarkan tingkat kepentingan yang mereka pahami mengenai keenam Prinsip.

Kegunaan Formulir: Kegunaan Formulir IA adalah untuk memperkirakan tingkat kepentingan relatif atau bobot tiap Prinsip dalam keseluruhan penilaian kelestarian hutan.

\begin{tabular}{|c|c|c|c|c|c|c|}
\hline \multirow[t]{2}{*}{ Prinsip } & \multirow[t]{2}{*}{ Peringkat } & \multirow[t]{2}{*}{ Nilai } & \multicolumn{3}{|c|}{$\begin{array}{l}\text { Bobot/Prioritas Relatif } \\
\text { (Diisi oleh Analis) }\end{array}$} & \multirow[t]{2}{*}{$\begin{array}{l}\text { Keterang- } \\
\text { an }\end{array}$} \\
\hline & & & $\begin{array}{l}\text { Peringkat } \\
\text { (Prioritas) }\end{array}$ & $\begin{array}{c}\text { Nilai } \\
\text { (Prioritas) }\end{array}$ & \begin{tabular}{|c|} 
Keseluruhan \\
(Prioritas)
\end{tabular} & \\
\hline \multicolumn{7}{|l|}{ Prinsip 1} \\
\hline \multicolumn{7}{|l|}{ Prinsip 2} \\
\hline \multicolumn{7}{|l|}{ Prinsip 3} \\
\hline \multicolumn{7}{|l|}{ Prinsip 4} \\
\hline \multicolumn{7}{|l|}{ Prinsip 5} \\
\hline Prinsip 6 & & & & & & \\
\hline & & Total $=100$ & & & & \\
\hline
\end{tabular}




\section{Formulir Respon 1B}

(Silakan merujuk pada Pola Generik CIFOR untuk Informasi Terinci mengenai Kriteria dan Indikator)

Deskripsi: Formulir Respon 1B dirancang untuk Analisis Tingkat 2 pada Tahap 1. Pada Tingkat 2 diperoleh respon dari para responden tentang pendapat mereka mengenai tingkat kepentingan relatif tiap Kriteria terhadap Prinsip, pada khususnya, dan kelestarian hutan keseluruhan, pada umumnya.

Kegunaan Formulir: Kegunaan Formulir 1B adalah untuk memperkirakan tingkat kepentingan relatif atau bobot tiap kriteria dalam tiap Prinsip.

Penentuan Kode dari Kriteria: K. i.j; i menunjukkan angka indeks Prinsip; j menunjukkan angka indeks Kriteria

\begin{tabular}{|c|c|c|c|c|c|c|}
\hline$\frac{\text { Prinsip } 1}{\text { Kriteria }}$ & \multirow[t]{2}{*}{ Peringkat } & \multirow[t]{2}{*}{ Nilai } & \multicolumn{3}{|c|}{$\begin{array}{c}\text { Bobot/Prioritas Relatif } \\
\text { (Diisi oleh Analis) }\end{array}$} & \multirow[t]{2}{*}{$\begin{array}{l}\text { Keterang- } \\
\text { an }\end{array}$} \\
\hline & & & $\begin{array}{l}\text { Peringkat } \\
\text { (Prioritas) }\end{array}$ & $\begin{array}{c}\text { Nilai } \\
\text { (Prioritas) }\end{array}$ & $\begin{array}{c}\text { Keseluruhan } \\
\text { (Prioritas) }\end{array}$ & \\
\hline K. 1.1 & & & & & & \\
\hline K. 1.2 & & & & & & \\
\hline K. 1.3 & & & & & & \\
\hline K. 1.4 & & & & & & \\
\hline K. 1.5 & & & & & & \\
\hline K. 1.6 & & & & & & \\
\hline & & Total $=100$ & & & & \\
\hline
\end{tabular}




\begin{tabular}{|c|c|c|c|c|c|c|}
\hline$\frac{\text { Prinsip } 2}{\text { Kriteria }}$ & \multirow[t]{2}{*}{ Peringkat } & \multirow[t]{2}{*}{ Nilai } & \multicolumn{3}{|c|}{$\begin{array}{c}\text { Bobot/Prioritas Relatif } \\
\text { (Diisi oleh Analis) }\end{array}$} & \multirow[t]{2}{*}{$\begin{array}{l}\text { Keterang- } \\
\text { an }\end{array}$} \\
\hline & & & $\begin{array}{l}\text { Peringkat } \\
\text { (Prioritas) }\end{array}$ & $\begin{array}{c}\text { Nilai } \\
\text { (Prioritas) }\end{array}$ & \begin{tabular}{|c|} 
Keseluruhan \\
(Prioritas)
\end{tabular} & \\
\hline K. 2.1 & & & & & & \\
\hline K. 2.2 & & & & & & \\
\hline K. 2.3 & & & & & & \\
\hline & & Total $=100$ & & & & \\
\hline
\end{tabular}

\section{Formulir Respon 2A: Perbandingan Berpasangan}

(Silakan merujuk pada Pola Generik K\&I CIFOR untuk Informasi Terinci mengenai Kriteria dan Indikator)

Deskripsi: Formulir Respon 2A dirancang untuk Analisis Tahap 2. Tahap 2 bertujuan menghasilkan suatu daftar prioritas Indikator untuk tiap Kriteria.

Kegunaan Formulir: Kegunaan formulir adalah untuk memperkirakan tingkat kepentingan relatif atau bobot tiap Indikator dalam Kriteria dengan menggunakan metode Perbandingan Berpasangan.

\begin{tabular}{|c|c|c|c|c|c|c|c|c|c|c|c|c|c|c|c|c|c|c|}
\hline Indikator $\mathrm{A}$ & \multicolumn{17}{|c|}{ Kriteria K. 1.1} & Indikator B \\
\hline I. 1.1.1 & 9 & 8 & & 6 & 5 & & 3 & & & 2 & 3 & 4 & & & & & 9 & I. 1.1 .2 \\
\hline I. 1.1.1 & 9 & 8 & 7 & 6 & 5 & & 3 & & 1 & 2 & 3 & 4 & 5 & 6 & 7 & 8 & 9 & I. 1.1.3 \\
\hline I. 1.1.1 & 9 & 8 & 7 & 6 & 5 & & & & & $\underline{L}$ & 3 & 4 & 5 & 6 & 7 & 8 & 9 & I. 1.1.4 \\
\hline I. 1.1.1 & 9 & 8 & 7 & 6 & 5 & & 3 & & $\frac{1}{1}$ & 2 & 3 & 4 & 5 & 6 & 7 & 8 & 9 & I. 1.1 .5 \\
\hline I. 1.1.2 & 9 & 8 & 7 & 6 & 5 & & 3 & & 1 & 2 & 3 & 4 & 5 & 6 & 7 & 8 & 9 & I. 1.1 .3 \\
\hline I. 1.1.2 & 9 & 8 & 7 & 6 & 5 & & 3 & & 1 & 2 & 3 & 4 & 5 & 6 & 7 & 8 & 9 & I. 1.1.4 \\
\hline I. 1.1 .2 & 9 & 8 & 7 & 6 & 5 & & 3 & & 1 & 2 & 3 & 4 & 5 & 6 & 7 & 8 & 9 & I. 1.1 .5 \\
\hline I. 1.1 .3 & 9 & 8 & 7 & 6 & 5 & & f & & 1 & 2 & 3 & 4 & 5 & 6 & 7 & 8 & 9 & I. 1.1.4 \\
\hline I. 1.1 .3 & 9 & 8 & 7 & 6 & 5 & & 3 & & 1 & 2 & 3 & 4 & 5 & 6 & 7 & 8 & 9 & I. 1.1 .5 \\
\hline I. 1.1.4 & 9 & 8 & 1 & 6 & 5 & & & & & & 3 & 4 & & & & 8 & 9 & I. 1.1 .5 \\
\hline
\end{tabular}




\subsection{POLA GENERIK KRITERIA DAN INDIKATOR CIFOR*}

(Tanpa Pengukur/Verifier)

\begin{tabular}{|c|c|c|c|}
\hline $\mathbf{P}$ & $\mathrm{K}$ & I & DESKRIPSI \\
\hline $\mathbf{1}$ & & & $\begin{array}{l}\text { KEBIJAKAN, PERENCANAAN DAN KERANGKA KELEMBA- } \\
\text { GAAN MENDUKUNG PENGELOLAAN HUTAN LESTARI }\end{array}$ \\
\hline & 1.1 & & $\begin{array}{l}\text { Dana untuk pengelolaan hutan selalu tersedia dan dalam jumlah } \\
\text { yang memadai }\end{array}$ \\
\hline & & 1.1.1 & $\begin{array}{l}\text { Kebijakan dan perencanaan didasarkan atas informasi yang akurat dan } \\
\text { terkini }\end{array}$ \\
\hline & & 1.1 .2 & $\begin{array}{l}\text { Ada cara-cara yang efektif dalam koordinasi antarlembaga dalam hal } \\
\text { tata guna lahan dan pengelolaan lahan }\end{array}$ \\
\hline & & 1.1 .3 & $\begin{array}{l}\text { Adanya kawasan hutan permanen yang merupakan basis pengelolaan } \\
\text { hutan lestari, yang mencakup hutan lindung dan hutan produksi, dan } \\
\text { dilindungi oleh undang-undang }\end{array}$ \\
\hline & & 1.1 .4 & $\begin{array}{l}\text { Ada rencana tata guna lahan regional, yang menggambarkan berbagai } \\
\text { macam peruntukan lahan hutan, yang memperhatikan nilai-nilai berbagai } \\
\text { faktor seperti jumlah penduduk, pertanian, konservasi, lingkungan dan } \\
\text { budaya }\end{array}$ \\
\hline & & 1.1 .5 & $\begin{array}{l}\text { Lembaga-lembaga yang bertanggung jawab untuk pengelolaan hutan } \\
\text { dan penelitian mendapat dana dan tenaga yang memadai }\end{array}$ \\
\hline & 1.2 & & Ada kebijakan ekonomi yang bersifat pencegahan \\
\hline & & 1.2 .1 & $\begin{array}{l}\text { Ada dana cadangan untuk mengatasi kerusakan yang mungkin terjadi } \\
\text { (performance bond) }\end{array}$ \\
\hline
\end{tabular}

* Dikutip dari Seri No. 2 Perangkat Kriteria \& Indikator CIFOR. 


\begin{tabular}{|c|c|c|}
\hline & 1.2 .2 & Berbagai langkah untuk mencegah korupsi sudah dilaksanakan \\
\hline 1.3 & & Kebijakan nonkehutanan tidak mengganggu pengelolaan hutan \\
\hline & 1.3 .1 & Tidak ada insentif sektor pertanian untuk melakukan perluasan produksi \\
\hline & 1.3 .2 & Tidak ada pengendalian harga untuk produksi pangan dalam negeri \\
\hline & 1.3 .3 & Tidak ada pengendalian harga untuk minyak bahan bakar \\
\hline & 1.3 .4 & Tidak ada kebijakan pemukiman yang mengganggu \\
\hline & 1.3 .5 & $\begin{array}{l}\text { Tidak ada gangguan dari nilai tukar mata uang yang telalu tinggi atau terlalu } \\
\text { rendah }\end{array}$ \\
\hline 1.4 & & Ada daerah penyangga yang berfungsi dengan baik \\
\hline & 1.4 .1 & Tingkat konflik tata batas dalam unit pengelolaan hutan unit (UPH) rendah \\
\hline & 1.4 .2 & Masyarakat lokal menghormati tata batas UPH \\
\hline & 1.4 .3 & $\begin{array}{l}\text { Pengelola hutan (seperti HPH, Perusahaan kayu) menunjukkan berbagai } \\
\text { upaya untuk melindungi tata batas UPH }\end{array}$ \\
\hline 1.5 & & $\begin{array}{l}\text { Hukum dan perundang-undangan menjamin akses terhadap hutan } \\
\text { dan sumber daya hutan }\end{array}$ \\
\hline & 1.5 .1 & Keamanan kepemilikan yang jelas dan didokumentasikan dengan baik \\
\hline & 1.5 .2 & Ada kebijakan untuk tidak mengambil alih tata guna lahan yang ada \\
\hline & 1.5 .3 & $\begin{array}{l}\text { Ada hak untuk memungut hasil hutan nonkayu (HHNK) (misalnya, kayu } \\
\text { bakar) }\end{array}$ \\
\hline & 1.5 .4 & $\begin{array}{l}\text { Kebijakan hak kepemilikan lahan tidak mendiskriminasikan hak } \\
\text { atas hutan }\end{array}$ \\
\hline & 1.5 .5 & Kebijakan penetapan harga kayu bulat/ekspor kayu bulat efisien \\
\hline
\end{tabular}




\begin{tabular}{|c|c|c|c|}
\hline & & 1.5 .6 & Sistem alokasi lahan pengusahaan hutan berlangsung transparan \\
\hline & 1.6 & & Ada reinvestasi modal untuk berbagai pilihan kegiatan pemanfaatan hutan \\
\hline & & 1.6 .1 & $\begin{array}{l}\text { Tidak ada pelarian modal secara besar-besaran (mendorong 'tebang dan } \\
\text { lari') }\end{array}$ \\
\hline 2 & & & PEMELIHARAAN INTEGRITAS EKOSISTEM \\
\hline & 2.1 & & $\begin{array}{l}\text { Proses-proses yang menjaga keanekaragaman hayati di dalam hutan } \\
\text { yang dikelola (UPH) dilindungi }\end{array}$ \\
\hline & & 2.1 .1 & Pola-pola lansekap tetap dipertahankan \\
\hline & & 2.1 .2 & $\begin{array}{l}\text { Perubahan keragaman habitat akibat intervensi manusia tetap dipertahan-kan } \\
\text { di dalam batas kritisnya seperti ditetapkan oleh variasi alami dan/atau tujuan } \\
\text { konservasi }\end{array}$ \\
\hline & & 2.1 .3 & $\begin{array}{l}\text { Struktur relung (guilds) komunitas tertentu tidak menunjukkan perubahan } \\
\text { yang berarti, khususnya yang mewakili komunitas tertentu seperti kelom- } \\
\text { pok penyerbuk dan penyebar biji }\end{array}$ \\
\hline & & 2.1 .4 & $\begin{array}{l}\text { Tingkat kekayaan/keragaman kelompok-kelompok tertentu tidak menunjukkan } \\
\text { perubahan yang penting }\end{array}$ \\
\hline & & 2.1 .5 & $\begin{array}{l}\text { Ukuran populasi dan struktur demografi jenis-jenis tertentu tidak menun- } \\
\text { jukkan perubahan yang berarti, dan berbagai tahap dalam siklus kehidup-an } \\
\text { secara demografis dan ekologis tetap terwakili }\end{array}$ \\
\hline & & 2.1 .6 & Status pembusukan dan daur hara tidak menunjukkan perubahan yang berarti \\
\hline & & 2.1 .7 & $\begin{array}{l}\text { Tidak ada perubahan penting dalam hal kualitas dan kuantitas air dalam } \\
\text { daerah resapan air }\end{array}$ \\
\hline & 2.2 & & Berbagai fungsi ekosistem tetap dipelihara \\
\hline & & 2.2 .1 & Rantai makanan dan ekosistem tidak terkontaminasi oleh bahan kimia \\
\hline
\end{tabular}




\begin{tabular}{|c|c|c|c|}
\hline & & 2.2.2 & $\begin{array}{l}\text { Tempat-tempat yang rentan secara ekologis dilindungi, seperti daerah } \\
\text { penyangga yang berada di sepanjang aliran sungai }\end{array}$ \\
\hline & & 2.2.3 & $\begin{array}{l}\text { Tempat-tempat yang mewakili berbagai lokasi yang nilai ekologisnya penting } \\
\text { dilindungi atau dikelola secara tepat }\end{array}$ \\
\hline & & 2.2 .4 & Jenis hidupan yang langka atau terancam punah dilindungi \\
\hline & & 2.2 .5 & $\begin{array}{l}\text { Erosi dan bentuk-bentuk kemerosotan lahan lainnya dipertahankan sekecil } \\
\text { mungkin }\end{array}$ \\
\hline & 2.3 & & Konservasi berbagai proses untuk mempertahankan variasi genetis \\
\hline & & 2.3 .1 & $\begin{array}{l}\text { Berbagai tingkat keragaman genetis tetap dipertahankan dalam batas-batas } \\
\text { kritisnya }\end{array}$ \\
\hline & & 2.3.2 & Tidak ada perubahan arah frekuensi genotip \\
\hline & & 2.3 .3 & Tidak ada perubahan dalam aliran/migrasi gen \\
\hline & & 2.3.4 & Tidak ada perubahan dalam sistem perkawinan \\
\hline 3 & & & $\begin{array}{l}\text { PENGELOLAAN HUTAN MENJAGA ATAU MENINGKATKAN } \\
\text { AKSES ANTARGENERASI TERHADAP SUMBER DAYA DAN } \\
\text { BERBAGAI MANFAAT EKONOMI SECARA ADIL }\end{array}$ \\
\hline & 3.1 & & $\begin{array}{l}\text { Pihak pengelola lokal dapat secara efektif mengendalikan pemeliha- } \\
\text { raan dan akses terhadap sumber daya }\end{array}$ \\
\hline & & 3.1 .1 & $\begin{array}{l}\text { Kepemilikan dan hak pemanfaatan sumber daya (dalam satu generasi atau } \\
\text { antargenerasi) jelas dan mengakui klaim yang sudah ada }\end{array}$ \\
\hline & & 3.1 .2 & $\begin{array}{l}\text { Berbagai aturan dan norma dalam penggunaan sumber daya dipantau dan } \\
\text { ditegakkan pelaksanaannya }\end{array}$ \\
\hline & & 3.1 .3 & $\begin{array}{l}\text { Cara-cara untuk mengatasi konflik berfungsi baik tanpa } \\
\text { menggunakan kekerasan }\end{array}$ \\
\hline
\end{tabular}




\begin{tabular}{|c|c|c|}
\hline & 3.1 .4 & Akses terhadap sumber daya dianggap adil oleh masyarakat lokal \\
\hline & 3.1 .5 & Masyarakat lokal merasakan keamanan aksesnya terhadap sumber daya \\
\hline 3.2 & & $\begin{array}{l}\text { Para pengelola hutan memperoleh manfaat ekonomi yang cukup dari } \\
\text { hasil-hasil hutan yang diambilnya }\end{array}$ \\
\hline & 3.2 .1 & Mekanisme distribusi manfaat dianggap adil oleh masyarakat lokal \\
\hline & 3.2 .2 & $\begin{array}{l}\text { Adanya kesempatan bagi masyarakat lokal dan masyarakat yang meng- } \\
\text { gantungkan hidupnya pada hutan untuk memperoleh pekerjaan dari perusahaan- } \\
\text { perusahaan kehutanan }\end{array}$ \\
\hline & 3.2 .3 & Upah dan tunjangan lainnya sesuai dengan standar nasional dan/atau ILO \\
\hline & 3.2 .4 & Ganti rugi terhadap kerusakan diberikan secara adil \\
\hline & 3.2 .5 & Berbagai hasil hutan digunakan secara optimal dan adil \\
\hline 3.3 & & $\begin{array}{l}\text { Masyarakat mengaitkan masa depan mereka dan anak-anak mere-ka } \\
\text { dengan pengelolaan sumber daya hutan }\end{array}$ \\
\hline & 3.3 .1 & $\begin{array}{l}\text { Masyarakat menanamkan modal di lingkungannya (misalnya, waktu, tenaga, } \\
\text { uang) }\end{array}$ \\
\hline & 3.3 .2 & Tingkat migrasi keluar rendah \\
\hline & 3.3 .3 & $\begin{array}{l}\text { Masyarakat menyadari pentingnya keseimbangan antara jumlah pendu-duk } \\
\text { dengan pemanfaatan sumber daya alam }\end{array}$ \\
\hline & 3.3 .4 & $\begin{array}{l}\text { Anak-anak mendapatkan pendidikan (formal dan informal) tentang pengelolaan } \\
\text { sumber daya alam }\end{array}$ \\
\hline & 3.3 .5 & Perusakan sumber daya alam oleh masyarakat lokal jarang terjadi \\
\hline & 3.3 .6 & Masyarakat memelihara hubungan batin dengan lahan hutan \\
\hline
\end{tabular}




\begin{tabular}{|c|c|c|c|}
\hline 4 & & & $\begin{array}{l}\text { STAKEHOLDER YANG RELEVAN MEMILIKI HAK DAN } \\
\text { KEMAMPUAN YANG DIAKUI UNTUK MENGELOLA HUTAN } \\
\text { SECARA BERSAMA DAN ADIL }\end{array}$ \\
\hline & 4.1 & & $\begin{array}{l}\text { Adanya berbagai mekanisme yang efektif untuk melakukan komu- } \\
\text { nikasi dua arah antara para stakeholder dalam kaitannya dengan } \\
\text { pengelolaan hutan }\end{array}$ \\
\hline & & 4.1 .1 & $\begin{array}{l}>50 \% \text { dari pegawai Departemen Kehutanan dan Perkebunan dan karya- } \\
\text { wan HPH dapat berbicara dalam satu atau beberapa bahasa lokal, atau > } \\
50 \% \text { wanita lokal dapat menggunakan bahasa yang digunakan oleh HPH } \\
\text { dalam berinteraksi }\end{array}$ \\
\hline & & 4.1 .2 & $\begin{array}{l}\text { Para stakeholder lokal bertemu dengan frekuensi yang cukup, keragaman } \\
\text { lokal cukup terwakili, dan dengan kualitas interaksi yang cukup }\end{array}$ \\
\hline & & 4.1 .3 & $\begin{array}{l}\text { Kontribusi masing-masing stakeholder saling dihormati dan dihargai } \\
\text { secara wajar }\end{array}$ \\
\hline & 4.2 & & $\begin{array}{l}\text { Para stakeholder memiliki pengetahuan yang lengkap tentang peng- } \\
\text { gunaan sumber daya hutan (termasuk pengetahuan tentang kelom- } \\
\text { pok-kelompok pengguna hutan dan peranan jender), dan juga penge- } \\
\text { tahuan tentang rencana pengelolaan hutan sebelum rencana tersebut } \\
\text { dilaksanakan }\end{array}$ \\
\hline & & 4.2 .1 & $\begin{array}{l}\text { Adanya rencana/peta-peta yang menunjukkan pengintegrasian } \\
\text { berbagai penggunaan hutan oleh berbagai stakeholder yang berbeda }\end{array}$ \\
\hline & & 4.2 .2 & $\begin{array}{l}\text { Rencana yang diperbarui, studi-studi dasar dan peta dapat diperoleh } \\
\text { dengan mudah, yang menunjukkan rincian kawasan seperti penebangan } \\
\text { hutan dan pembangunan jalan, disertai kerangka waktunya }\end{array}$ \\
\hline & & 4.2 .3 & Studi-studi dasar tentang sistem masyarakat lokal juga tersedia dan diacu \\
\hline & & 4.2 .4 & $\begin{array}{l}\text { Pegawai pengelola hutan mengakui adanya berbagai kepentingan } \\
\text { dan hak stakeholder lainnya }\end{array}$ \\
\hline
\end{tabular}




\begin{tabular}{|c|c|c|c|}
\hline & & 4.2 .5 & $\begin{array}{l}\text { Pengelolaan HHNK mencerminkan kepentingan dan hak-hak stakeholder } \\
\text { lokal }\end{array}$ \\
\hline & 4.3 & & $\begin{array}{l}\text { Ada kesepakatan tentang hak-hak dan berbagai kewajiban stake-holder } \\
\text { yang relevan }\end{array}$ \\
\hline & & 4.3 .1 & Tingkat konflik yang ada dapat diterima oleh para stakeholder \\
\hline 5 & & & $\begin{array}{l}\text { KESEHATAN HUTAN, PARA PENGGUNA HUTAN DAN BUDA- } \\
\text { YANYA DAPAT DITERIMA OLEH SEMUA STAKEHOLDER }\end{array}$ \\
\hline & 5.1 & & $\begin{array}{l}\text { Ada keseimbangan yang cukup baik antara berbagai kegiatan manu- } \\
\text { sia dan kondisi lingkungannya }\end{array}$ \\
\hline & & 5.1 .1 & $\begin{array}{l}\text { Berbagai kondisi lingkungan yang dipengaruhi oleh kegiatan manusia tetap } \\
\text { dalam keadaan stabil atau membaik }\end{array}$ \\
\hline & & 5.1 .2 & $\begin{array}{l}\text { Migrasi masuk dan/atau pertambahan penduduk secara alami selaras dengan } \\
\text { pemeliharaan hutan }\end{array}$ \\
\hline & 5.2 & & $\begin{array}{l}\text { Ada pengakuan terhadap hubungan antara kesehatan masyarakat } \\
\text { dengan pengelolaan hutan }\end{array}$ \\
\hline & & 5.2 .1 & $\begin{array}{l}\text { Pihak pengelola hutan bekerjasama dengan petugas kesehatan masyarakat } \\
\text { dalam mengatasi berbagai penyakit yang berkaitan dengan pengelolaan hutan }\end{array}$ \\
\hline & & 5.2 .2 & $\begin{array}{l}\text { Status gizi masyarakat lokal cukup baik (misalnya, tingkat pertumbuhan } \\
\text { tinggi dan berat badan anak-anak sesuai dengan standar internasional, tingkat } \\
\text { kematian bayi dan balita rendah) }\end{array}$ \\
\hline & & 5.2 .3 & $\begin{array}{l}\text { Para pegawai yang bekerja di bidang kehutanan memperhatikan persya-ratan- } \\
\text { persyaratan dan keamanan kerja sesuai dengan standar ILO dan bertanggung } \\
\text { jawab atas risiko kesehatan yang berkaitan dengan pekerjaan mereka }\end{array}$ \\
\hline
\end{tabular}


PANDUAN MENERAPKAN ANALISIS, SERI NO. 9

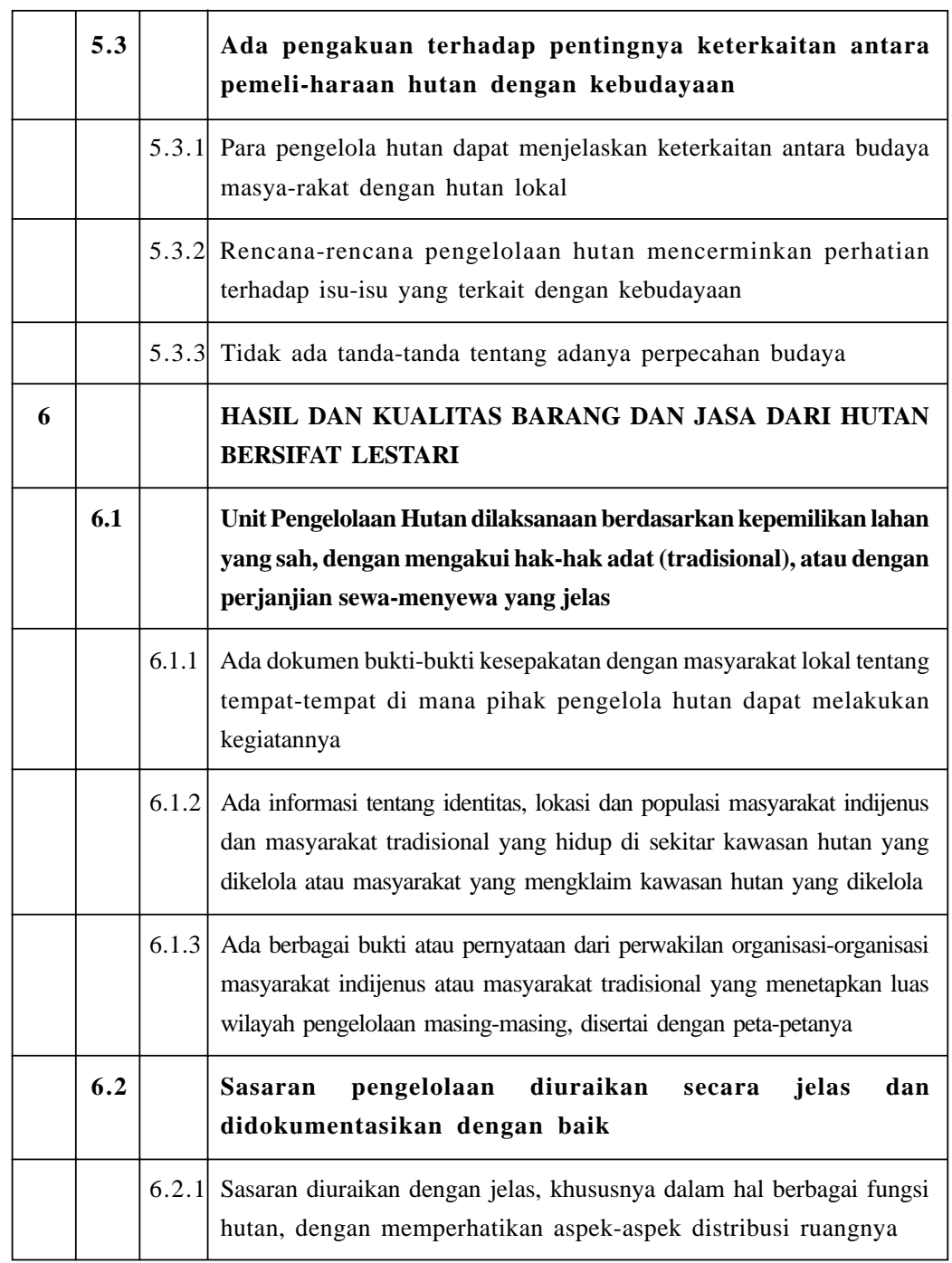




\begin{tabular}{|c|c|c|}
\hline 6.3 & & Rencana pengelolaan hutan bersifat komprehensif \\
\hline & 6.3 .1 & Tersedianya rencana pengelolaan hutan yang komprehensif \\
\hline & 6.3 .2 & $\begin{array}{l}\text { Pengelolaan melibatkan berbagai stakeholder yang tepat dan } \\
\text { mempertim-bangkan berbagai fungsi hutan, seperti produksi kayu, } \\
\text { HHNK, ekologi dan kesejahteraan masyarakat lokal }\end{array}$ \\
\hline & 6.3 .3 & $\begin{array}{l}\text { Aturan pengambilan hasil berdasarkan luas hutan atau volume hasil } \\
\text { disebutkan dengan jelas }\end{array}$ \\
\hline & 6.3 .4 & $\begin{array}{l}\text { Sistem silvikultur yang tepat dengan tipe hutan dan hasil hutan yang } \\
\text { diproduksi disebutkan dengan jelas }\end{array}$ \\
\hline & 6.3 .5 & $\begin{array}{l}\text { Sistem pemanenan dan peralatannya ditetapkan sesuai dengan kondisi } \\
\text { hutan untuk mengurangi dampak/pengaruh }\end{array}$ \\
\hline & 6.3 .6 & Rencana pengelolaan secara berkala diserahkan untuk direvisi \\
\hline 6.4 & & Implementasi rencana pengelolaan berlangsung efektif \\
\hline & 6.4 .1 & Unit-unit hutan dibuat zonasinya untuk berbagai tujuan pengelolaan \\
\hline & 6.4 .2 & Tata batas ditandai di lapangan \\
\hline & 6.4 .3 & $\begin{array}{l}\text { Hasil inventarisasi seluruh pemanfaatan hutan dan hasil-hasil hutannya } \\
\text { tersedia }\end{array}$ \\
\hline & 6.4 .4 & $\begin{array}{l}\text { Para karyawan mendapat pelatihan yang memadai untuk melaksanakan } \\
\text { pengelolaan }\end{array}$ \\
\hline & 6.4 .5 & $\begin{array}{l}\text { Infrastruktur disiapkan sebelum pemanenan dan dilakukan sesuai aturan- } \\
\text { aturan pemanenan }\end{array}$ \\
\hline & 6.4 .6 & Kerusakan terhadap tegakan sisa rendah \\
\hline
\end{tabular}




\begin{tabular}{|c|c|c|}
\hline & 6.4 .7 & $\begin{array}{l}\text { Rehabilitasi lahan dan hutan yang terkena dampak dilakukan sesuai } \\
\text { dengan aturan-aturan yang ditetapkan }\end{array}$ \\
\hline & 6.4 .8 & $\begin{array}{l}\text { Tidak ada dampak di luar lokasi seperti dampak kualitas/kuantitas air } \\
\text { di daerah hilir, dampak terhadap infrastruktur dsb. }\end{array}$ \\
\hline & 6.4 .9 & $\begin{array}{l}\text { Berbagai sistem untuk produksi dan transformasi hasil hutan berlangsung } \\
\text { efisien }\end{array}$ \\
\hline 6.5 & & $\begin{array}{l}\text { Sistem pemantauan dan sistem audit terhadap pengelolaan sesuai } \\
\text { dengan perencanaan }\end{array}$ \\
\hline & 6.5 .1 & $\begin{array}{l}\text { Petak-petak untuk inventarisasi hutan secara kontinu tetap ada dan } \\
\text { dihitung secara teratur }\end{array}$ \\
\hline & 6.5 .2 & $\begin{array}{l}\text { Semua dokumentasi dan catatan tentang pengelolaan hutan dan berbagai } \\
\text { kegiatan yang terkait dengan pengurusan hutan disimpan dalam kondisi } \\
\text { baik sehingga dapat dimanfaatkan untuk kepentingan pemantauan }\end{array}$ \\
\hline & 6.5 .3 & $\begin{array}{l}\text { Petak kerja dalam keadaan terlindung (misalnya, dari kebakaran, peram- } \\
\text { bahan hutan dan pemanfaatan kembali sebelum waktunya) }\end{array}$ \\
\hline & 6.5 .4 & $\begin{array}{l}\text { Penandaan pohon-pohon sebagai sumber biji dan pohon potensial untuk } \\
\text { pertumbuhan berikutnya dilakukan }\end{array}$ \\
\hline & 6.5 .5 & $\begin{array}{l}\text { Hasil-hasil yang berasal dari pemantauan dan penelitian, dan juga } \\
\text { ber-bagai informasi ilmiah dan teknis, dimasukkan ke dalam } \\
\text { implementasi dan revisi rencana pengelolaan }\end{array}$ \\
\hline 6.6 & & $\begin{array}{l}\text { Keberadaan dan distribusi keuntungan ekonomis } \\
\text { dilakukan secara adil }\end{array}$ \\
\hline & 6.6 .1 & Perkiraan rent capture pemerintah \\
\hline & 6.6 .2 & Perkiraan rent capture operator kehutanan \\
\hline & 6.6 .3 & Perkiraan rent capture masyarakat lokal di hutan \\
\hline
\end{tabular}


CATATAN:

$\mathrm{P}=$ PRINSIP $\quad \mathrm{K}=$ KRITERIA $\quad \mathrm{I}=$ INDIKATOR 


\section{SistemCGIAR}

The Consultative Group on International Agricultural Research (CGIAR) adalah suatu asosiasi informal yang terdiri dari 41 organisasi donor dari sektor publik dan swasta yang mendukung jaringan enam belas lembaga penelitian internasional di bidang pertanian, di mana CIFOR merupakan anggota terbaru. Asosiasi ini didirikan pada tahun 1971. Pusat-pusat CGIAR merupakan bagian sistem penelitian global di bidang pertanian yang berusaha menerapkan kemampuan ilmiah internasional untuk menyelesaikan masalah-masalah yang dihadapi olehmasyarakatmiskin di dunia.

\section{CIFOR}

CIFOR adalah bagian sistem CGIAR dengan tugas khusus untuk menanggapi kepedulian global tentang dampak kerusakan dan kehilangan hutan terhadap kondisi sosial, lingkungan dan ekonomi masyarakat. CIFOR beroperasi melalui berbagai kemitraan yang sangat terdesentralisasi dengan lembaga-lembaga dan/atau individu terpenting di seluruh negara industri dan negara yang sedang berkembang. Sifat dan jangka waktu kemitraan ini ditentukan oleh masalahmasalah penelitian khusus yang dihadapi. Agenda penelitian ini terus-menerus dikaji dan selalu mengalami perubahan ketika para mitra menemukan berbagai masalah dan peluang baru. 
Analisis Multikriteria adalah perangkat pengambilan keputusan yang dikembangkan untuk masalah-masalah kompleks. Dalam situasi pengambilan keputusan yang melibatkan banyak kriteria, kerancuan mungkin akan terjadi jika suatu proses pengambilan keputusan yang logis dan terstruktur dengan baik tidak diikuti. Kesulitan lain yang dihadapi dalam pengambilan keputusan seperti ini adalah bagaimana mencapai kesepakatan bersama dalam suatu tim yang terdiri dari berbagai disiplin ilmu. Dengan menggunakan AMK, para anggota tidak harus sepakat mengenai tingkat kepentingan relatif suatu Kriteria atau mengenai penetapan peringkat alternatifnya. Tiap anggota tim menyatakan pendapat pribadinya, dan memberi sumbangan masingmasing dalam rangka tercapainya kesimpulan yang disepakati bersama.

Panduan ini ditulis untuk pengguna yangmemerlukan panduan yang jelas dan mudah diikuti untuk menerapkan Analisis Multikriteria (AMK) di lapangan. Informasi yang disajikan dalam panduan ini pertama memperkenalkan pengguna dengan konsep-konsep umum yang digunakan sebelum membahas aplikasi Analisis Multikriteria secara lebih spesifik. Panduan ini menyajikan kajian tentang kerangka konseptual K\&I dan memperkenalkan landasan teori AMK, serta berbagai metode seperti penetapan nilai, penetapan peringkat, dan perbandingan berpasangan dalam Proses Hierarki Analitik (PHA). Panduan ini juga menyajikan suatu contoh bagaimana menerapkan AMK dalam menilai K\&I dalam konteks sertifikasi hutan, dari perspektif 'top-down' maupun 'bottom-up'. 